\title{
Hadrianoupolis Kuzeybatı Nekropol Kilisesi’nin Bema ve Apsis Mozaikleri
}

\section{Mosaics of Bema and Apse in Northwest Necropolis Church from Hadrianoupolis}

\author{
Ersin ÇELİKBAŞ - Ercan VERIM**
}

(Received 03 May 2021, accepted after revision 03 September 2021)

\begin{abstract}
Öz
Paphlagonia sınırlarındaki Hadrianoupolis Antik Kentinde, 2003-2020 yılları arasında, Geç Antik Çă̆’a tarihlenen altı yapıda kazı çalışması yapılmış ve bu çalışmalarda dönemin süsleme karakterini yansıtan zemin mozaiklerine rastlanılmıştır. Kazısı hâlen devam eden, yayınlarda daha çok Kuzeybatı Nekropol Kilisesi olarak tanitılan, kentteki konumu itibariyle Kuzeybatı Nekropol Kilisesi şeklinde adlandirılabilecek yapının, apsis ve bema zemininde de kaliteli işçilikte zemin mozaikleri tespit edilmiştir. İki farkl inşa evresine sahip kilisenin zemini her iki dönemde farkl teknik ve üsluptaki mozaikle bezenmiştir. Bir kısmı geçmiş dönemde gerçekleşen kaçak kazılar ve yol yapım çalışmaları esnasında tahrip olan, 2017-2018 yılındaki kazılarda tamamen ortaya çıkarılan mozaikler, IS 4.-6. yüzyıl Bizans mozaik sanatı karakterini yansitmaktadır. Dönemin hemen her zemin mozaiğinde görülen geometrik, bitkisel ve figüratif desenleriyle donatılmış mozaiklerde, bani bilgisi içeren bir de yazıt bulunmuştur. Restoratör ve konservatörler eşliğinde sağlamlaştırma çalışması yapılan mozaikler, uygun teknikler doğrultusunda koruma altına alınmıştır. Bu çalışmada, kilisenin apsis ve bema zeminlerini süsleyen mozaikler, bölge ve farklı coğrafyalardaki benzer örneklerle klyaslanmış ve değerlendirilmesi yapılarak ayrıntılı şekilde açıklanmaya çalışılmıştır.
\end{abstract}

Anahtar Kelimeler: Paphlagonia, Hadrianoupolis, Kuzeybatı Nekropol Kilisesi, Bizans, mozaik, katekümen.

\begin{abstract}
Excavations were carried out between 2003-2020 in the Hadrianoupolis from the Paphlagonia Region six buildings dated to the Late Antiquity and floor mosaics were found that reflect the period's decoration characteristics. High quality workmanship floor mosaics were found on the apse and bema floors of the building, in which excavation is still ongoing, and which can be named as the Northwest Necropolis Church due to its location in the city, which is mostly referred to as Northwest Necropolis Church in publications. The floor of the church, which has two different construction phases, was decorated with mosaics in different techniques and styles in both periods. The mosaics, some of which were destroyed during illegal excavations and road construction works in the past, and completely unearthed in 2017-2018 excavations, reflect the 4-6 $6^{\text {th }}$ AD century Byzantine mosaic art style. In the mosaics decorated with geometric, floral and figurative patterns seen on almost every floor mosaic of the period, an inscription containing information about the constructor was found. The mosaics, which were strengthened under the supervision of restorators and conservators, were preserved in accordance with appropriate techniques. In this study, the mosaics adorning the apse and bema floors of the church were compared and evaluated with similar examples in the region and different geographies and explained in detail.
\end{abstract}

Keywords: Paphlagonia, Hadrianoupolis, Northwest Necropolis Church, Byzantium, mosaic, catechumen.

\footnotetext{
* Ersin Çelikbaş, Karabük Üniversitesi, Edebiyat Fakültesi, Arkeoloji Bölümü, Karabük, Türkiye. (D) https://orcid.org/0000-0001-7630-4615. E-posta: ersincelikbas@gmail.com
} 


\section{Giriş}

"Paphlagonia Hadrianoupolis'i" olarak adlandırılan yer bugün Karabük ili, Eskipazar ilçe merkezinin $3 \mathrm{~km}$ batısında "Viranşehir" olarak adlandırılan mevkide, Budaklar Köyü ve Hacamatlar Mahallesi arasındaki derin bir vadide yer almaktadır. Günümüze ulaşan kalıntılar Budaklar, Büyükyayalar, Çaylı ve Beytarla köyleri ile Hacamatlar Mahallesi’nde yoğunlaşmaktadır (Res. 1).

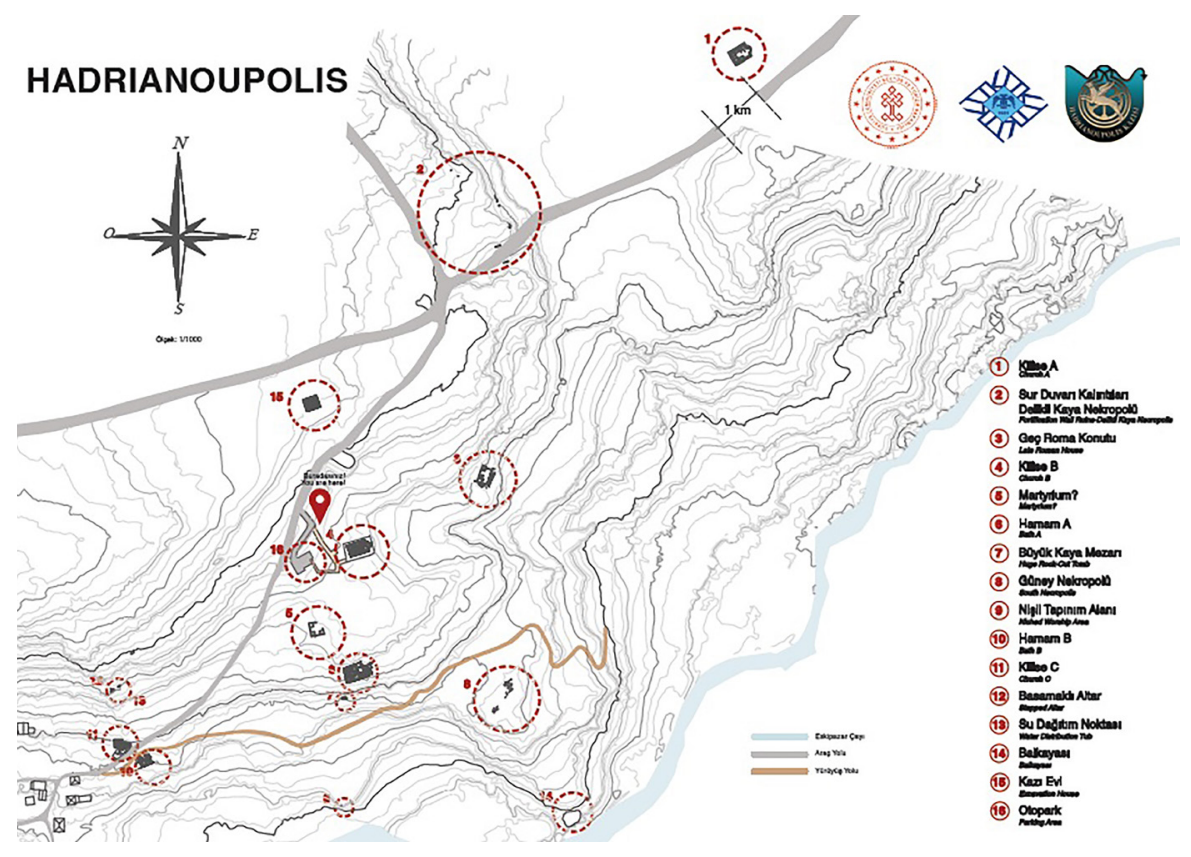

Paphlagonia Hadrianoupolisi'nin tarihsel sürecine bakıldığında, özellikle Roma İmparatorluk (İÖ 2. - İS 4. yüzy1l) ve Geç Roma - Erken Bizans Dönemi’nde (İS 330-565) hem idari hem de dini açıdan en parlak dönemini yaşadığı söylenebilir (Leonhard 1915: 147; Schultze 1922: 228-229; Belke 1996: 156; Kan Şahin 2019: 15; Verim 2019: 277-280). 2003 y1lında bilimsel kazı çalışmalarının başladığı antik kentte günümüze kadar altı yapı kalıntısı ortaya çıkarılmış olup, yapıların hepsinin Geç Roma - Erken Bizans Dönemi'ne ait oldukları anlaşılmıştır (Kılavuz - Çelikbaş 2013: 163-175; Keleş vd. 2014: 271290). Ortaya çıkarılan yapılardan üçü kilise, ikisi hamam, biri de konut yapısıdır. Çalışmanın konusunu oluşturan mozaikler de kentte ortaya çıkarılan üçüncü dini yapı olan Kuzeybatı Nekropol Kilisesi'nin bema ve apsisinde gün yüzüne çıkarılmıştır.

\section{Kuzeybatı Nekropol Kilisesi'ndeki Bilimsel Çalışmalar}

Doğu-batı doğrultusunda inşa edildiği anlaşılan kilisenin doğusundan asfalt köy yolu geçmektedir. 2007 yılı öncesinde gerçekleştirilen yol kazısı esnasında apsisin bir bölümü ile güneydoğu köşesi tahrip edilmiştir. 2007 yılında, E. Laflı başkanlığında yürütülen kazı çalışmalarında apsis bölümü kısmen ortaya çıkarılmış (Laflı - Zäh 2009: 654), ilk bulgular ışı̆̆ında yapı kalıntısı "Apsidal (Apsisli) Yapı" olarak tanımlanmış ve bazı yayınlarda mevcut kalıntılar, mozaik zemini hakkında kısa bilgiler sunulmuştur (Lafl1 - Zäh 2008: 654; Patacı 2012: 165-166; Patac1 - Laflı 2019: 209). 2012 yılında yapının apsis beden duvarları ortaya çıkarılmış, mozaik zemininde restorasyon çalışmaları gerçekleştirilmiştir. 2013 yılında yapı kalıntısının bulunduğu alanda arkeojeofizik çalışmalar yapılmış, Apsisli Yapı olarak adlandırılan yapının kilise olduğu saptanmıştır.
Resim 1

Hadrianoupolis Kent Planı (Kazı Arşivi). 
Ortaya çıkan bulgular bazı yayınlara konu olsa da kazısı yapılmadığı için kilise hakkında detaylı ve net bilgiler sunulamamıştır (Kılavuz - Çelikbaş 2013: 175-176; Keleş vd. 2014: 276; Keleş vd. 2015: 662-663). 2017 yılında yapıda kapsamlı bilimsel kazı çalışmaları başlatılmış olup yapının apsis, bema ve kuzey nefinin bir kısmı ortaya çıkarılmıştır. 2018-2020 yılları arasında yapıdaki kazıları E. Verim yönetmiş; kilisenin naos, apsis, bema kısımları tamamen, nartheksi ise batı duvarı haricinde büyük oranda ortaya çıkarılmıştır (Çelikbaş 2019a: 73-82; Çelikbaş 2019b: 290-295; Verim 2019: 283-284). Bu kazılarda kilise haricinde, yapının kuzeyinde şarap işliği ve işlevi henüz belirlenemeyen ek mekânlar, cam atölyesi?, cadde kalıntısı ve bir yapı kalıntısı (tapınak veya nymphaeum?) olduğu tespit edilmiştir. Kilisenin yapıldığ 1 düzeltilmiş arazide çok tabakalı bir yerleşim olduğu, kilisenin altında çıkan daire formlu yapı kalıntısından anlaşılmaktadır. Farklı dönemlere ait yapıların inşa edildiği bu arazinin sürekli tercih edilmesinde, arazinin kentin en merkezi noktalarından bir tanesi ile hazır teraslandırılmış bir alan olmasının payı büyüktür.

\section{Kuzeybatı Nekropol Kilisesi}

Yap1 kalıntıs1 Hacahmatlar Mahallesi'nin girişinde, Hadrianoupolis'in güneybatısında bulunur. Hamam B yapısının $20 \mathrm{~m}$ kuzeybatısında yer alan kilise, günümüzdeki adıyla Budaklar Köyü Topraklık Mevkii'nde, 4055’25.26 K-32²9'16.17 D koordinatlarında yer almaktadır. Kilisenin özgün adı, inşa tarihi veya kime ithaf edildiğine dair net veriler bulunmamaktadır. İnşa edildikten yaklaşık 100 yıl sonra çok büyük bir değişikliğe uğrayarak işlevine devam eden kilisede yapılan kazı çalışmaları sonucunda kilisenin dört tabakadan oluşan bir stratigrafiye sahip olduğu tespit edilmiştir (Res. 2). Sikke, seramik, madeni eserler ve mozaik gibi buluntular ile mimari özellikleri ışığında I. tabaka İS 8 .

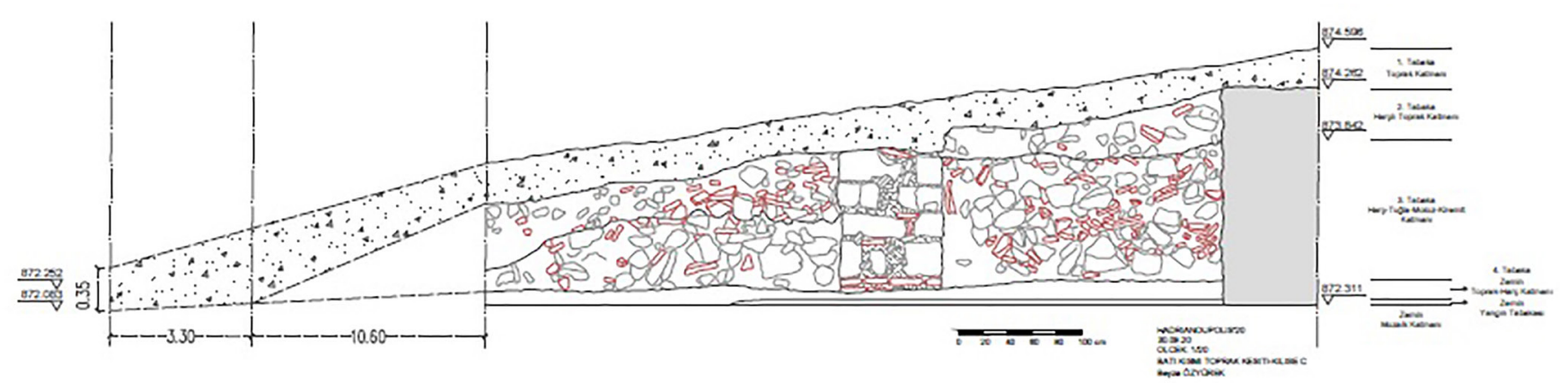

Resim 2

Kuzeybatı Nekropol Kilisesi Kazı Alanı Stratigrafisi (Kazı Arşivi). yüzyıla, II. tabaka İS 7. yüzyılın sonu - 8. yüzyıl arasına, III. Tabaka İS 5. 6. yüzyıl arasına, IV. Tabaka ise İS 4. - 6. yüzyıl arasına tarihlendirilmektedir. I. Tabaka, kilisenin yıkılmasından sonraki yüzyıldan günümüze kadar devam eden süreci kapsamaktadır ${ }^{1}$. II. Tabaka kilisenin fonksiyonunu yitirip yıkıldı̆̆ 1 döneme ve bu dönemden sonraki yüzyıla dair buluntuların görüldüğü, içeriğinde kiremit, tuğla, ahşap parçalarının yoğun olarak görüldüğü katmandır. III. Tabaka, kilisenin ikinci inşa evresi ile yıkım süreci arasındaki buluntulara rastlanılan tabakadır. Bu tabakada İS 6. - 7. yüzyıl arasına tarihlenen sikke, seramik, cam ve madeni eser parçalarına sıklıkla rastlanılmıştır. IV. Tabaka, ilk inşa evresi zemini ile ikinci inşa evresi zemini arasındaki tabakadır. İki zemin arasındaki tabakada, İS 4.- 6. yüzyıl arasında tarihlenen sikke, seramik, tuğla ve cam buluntulara rastlanılmıştır (Çelikbaş 2019a: 76; Oyarçin 2019: 442-446). Stratigrafi ve mimari detaylar, kilisenin ilk inşa evresinin İS 4. - 5. yüzyıl arasında olduğunu, kilisenin bir deprem ya da yangın sonucunda yıkıldığına işaret etmektedir. Burada bahsi

1 Bu katmanda Geç Osmanlı Dönemi’ne (18. yüzyıl - 1922) tarihlenebilecek at nalı ve seramik parçaları ile Cumhuriyet Dönemi'ne ait pantolon düğmeleri, gazoz kapakları gibi buluntulara rastlanılmıştır. 
geçen deprem, muhtemelen İS 443 yılı civarında Heracleia Pontica başta olmak üzere Honorias eyaletinde büyük yıkımlara sebebiyet vermiş deprem olabilir. (Schultze 1922: 231; Hoepfner 1966: 97; Roueché 1986: 130; Belke 1996: 6566). Bu yıkımın hemen ardından, hızlı bir inşa programıyla yeniden yapılmıştır²

İki farklı inşa evresine sahip Kuzeybatı Nekropol Kilisesi’nin ilk inşa evresine dair pek fazla veri bulunmamaktadır. İlk inşa evresine dair bulgular, ikinci inşa evresi zemininin $29 \mathrm{~cm}$ altında tespit edilen bema ve apsis mozaiğinden ve bemadaki kiborium izlerinden ibarettir. 2017-2020 yıllarındaki kazı çalışmalarında, daha çok ikinci inşa evresine dair bulgulara ulaşılmıştır. Mevcut bulgulara göre kilise, her iki inşa evresinde de doğu-batı doğrultusunda, üç nefli bazilikal planlı düzenlenmiştir (Res. 3). Yapı, ikinci inşa evresinde 25 x $15 \mathrm{~m}$ ölçülerinde düzenlenmiştir ${ }^{3}$. Kilisenin dikdörtgen formlu olan nartheksi, $13 \mathrm{x}$ $2.70 \mathrm{~m}$ ölçülerinde, içte yarım daire formunda dışta beş kenarlı düzenlenen, cepheden $4 \mathrm{~m}$ dışa taşkın apsisi ise içten $4.70 \times 3.85 \mathrm{~m}$ ölçülerindedir. Naosun ana mekânı niteliğindeki orta nef, 15 x 2.45 m ölçülerindeki yan neflere oranla daha geniş olup, 11.50 x 6.70 m ölçülerindedir ${ }^{4}$.
Resim 3

Kuzeybatı Nekropol Kilisesi Havadan Görüntüsü (Kazı Arşivi).

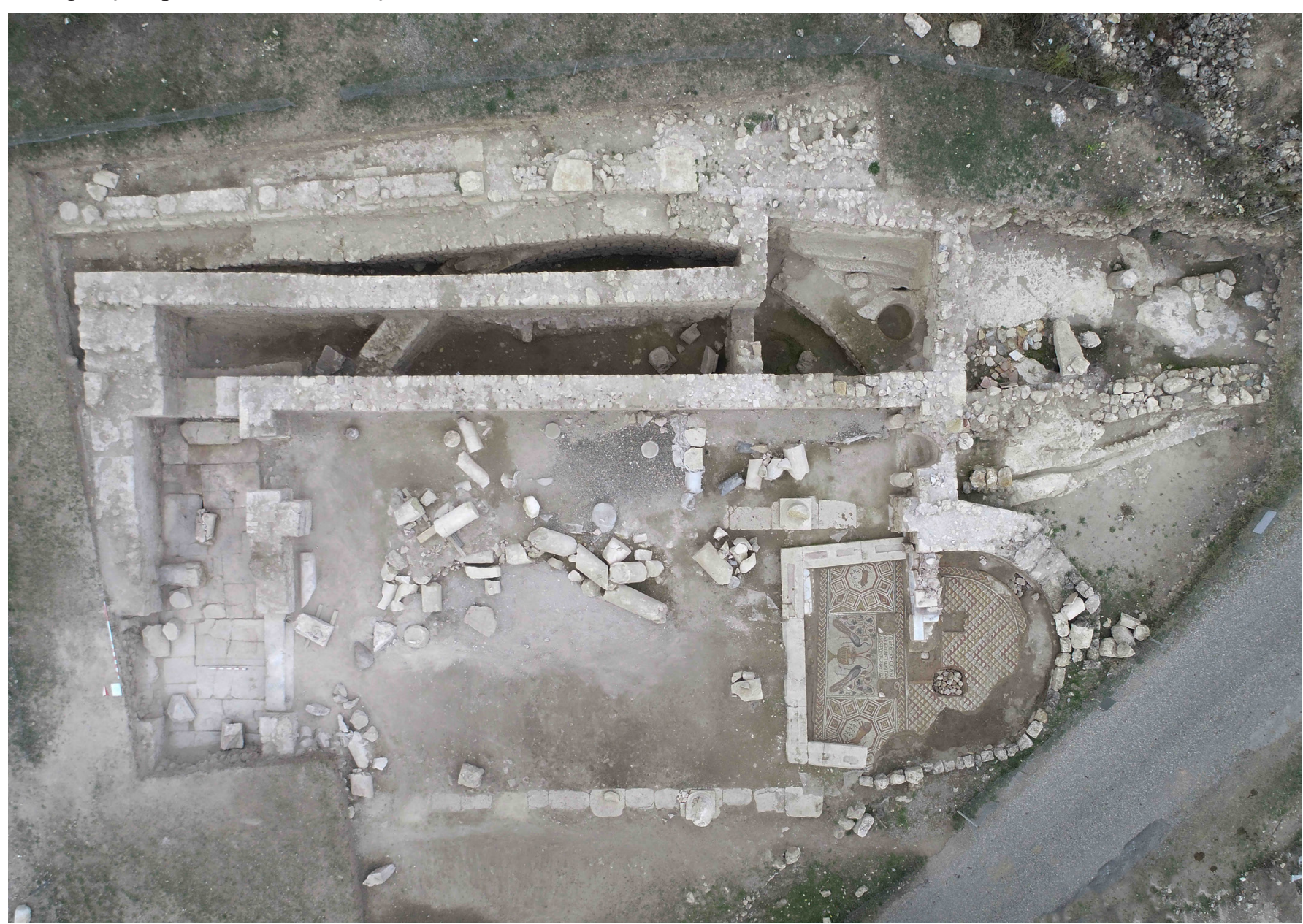

2 İkinci inşa evresinde kullanılan mimari parçalar ve duvar işçiliğinde bir özensizlik göze çarpar. Templon stylobatını oluşturan bloklar farklı ölçülerdedir ve kentteki diğer templon stylobatlarına göre daha kalitesiz iş̧̧iliğe sahiptir. Ayrıca templon stylobatına yatay-dikey düzlemde bakıldığında hafif eksen kayması da görülür. Benzer hususlar diğer mimari elemanlar ve duvar işçiliği için de geçerlidir. Duvardaki yapı malzemelerinde bakıldığında çok sayıda devşirme malzeme kullanıldığı da görülmektedir.

3 İlk inşa evresi zemin mozaiklerinin ikinci inşa evresi beden duvarlarına doğru devam etmesi, ilk inşa evresinde bema ve apsisinin daha büyük boyutlu düzenlenmiş olması gibi hususlar, yapının ilk inşa evresinde, ikincisine göre daha büyük boyutlu düzenlenmiş olduğunu göstermektedir.

4 Orta nefin önemli kısmını kaplayan bema, ölçülere dahil edilmemiştir. Neflerin ölçüleri verilirken bunları birbirinden ayıran sütunların oturduğu $70 \mathrm{~cm}$ genişlikteki nef stylobatlatları dahil edilmemiştir. 


\section{Bema ve Apsis Mozaikleri}

Çalışmanın konusunu oluşturan bema ve apsis zemin mozaikleri, kilisenin inşa evreleri baz alınarak iki evrede incelenmiştir. İlk evrede, bema ve apsis zemini bitişik ele alınmıştır (Res. 4). Orta ekseninde, iki panelin kesiştikleri alanda (apsisin batısı-bemanın doğusu) kiboriumla örtülü altarın bulunduğu bölüm yer

Resim 4

Apsis ve Bema Genel Görünüm

(Kazı Arşivi).

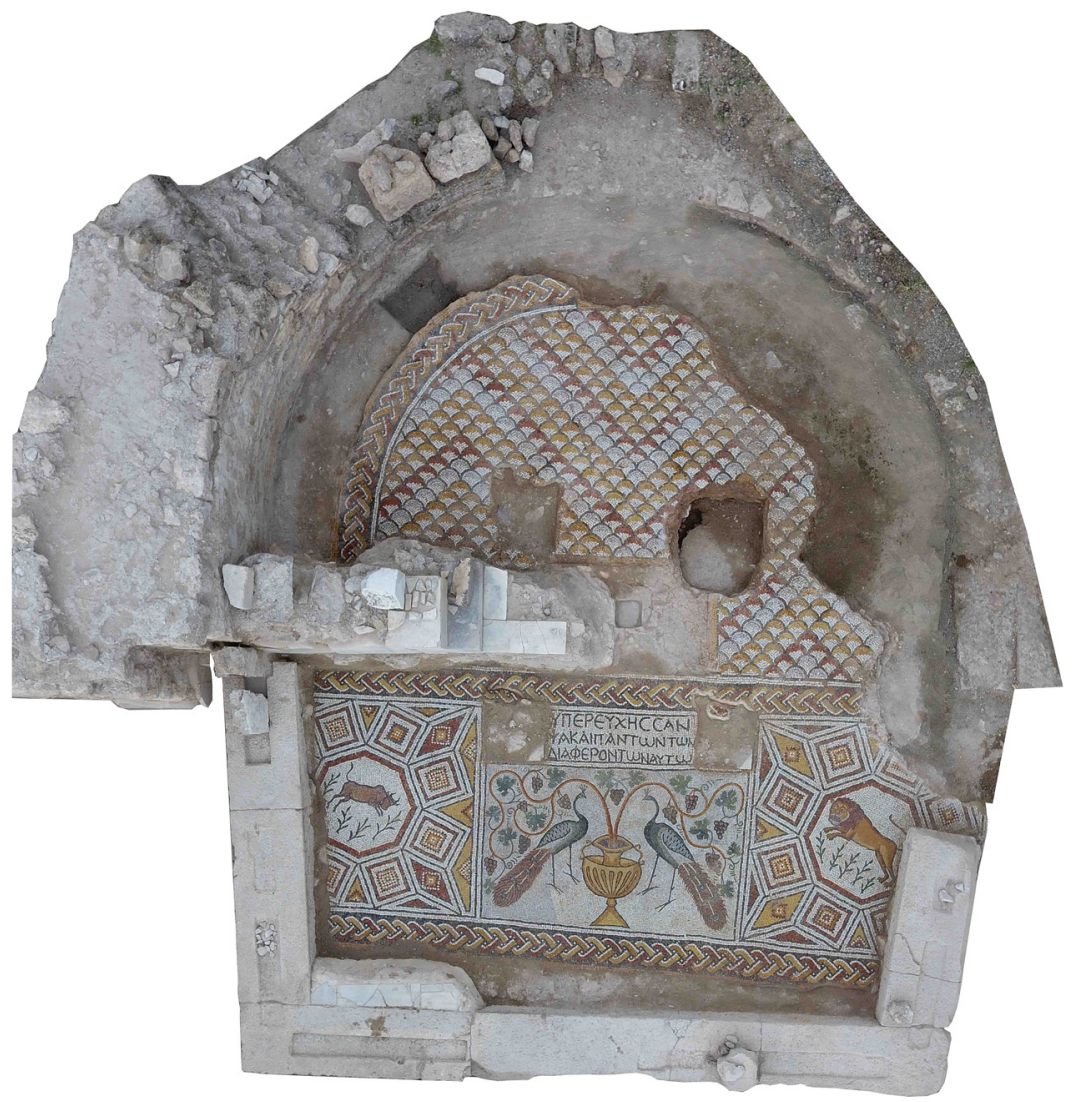

alır. Kilisenin yeniden yapımı esnasında bu bölüm ortadan kaldırılmış olmasına rağmen, kiborium ayakları ve altarın bulunduğu dikdörtgen alanı çevreleyen bordür kısmen korunmuştur. Kiboriumun kuzeydoğu ve güneydoğu ayakları, kaçak kazılar sonucu tamamen ortadan kaldırılmış olmakla birlikte kuzeybatı ve güneybatı ayaklarının kaide kısımları ise kısmen görülebilmektedir. İkinci evrede bema ve apsis zemini, ilk evreye göre $29 \mathrm{~cm}$ yüksek tutulmuştur. Bazı kısımları tahrip olmasına rağmen ilk evre zemin mozaiği büyük oranda korunmuş, hatta iyi bir şekilde korunması için ilk evre zemini üzerine bir koruma tabakası yapılmıştır. Bu durum ikinci evre mozaik tabakasının, Bizans Dönemi'ndeki diğer mozaik tabakalarına göre farklı olmasını sağlamıştır. Roma ve Bizans Dönemi'nde mozaik döşemeler, alttan üste doğru sırasıyla; statumen, rudus, nucleus, yatak harc1 ve tesssellatum tabakalarından oluşmaktadır. Kuzeybatı Nekropol Kilisesi bema bölümünün ikinci evre mozaik döşemesinin tabakasına bakıldığında ise nucleus'a yer verilmediği, bununla birlikte yedi katmandan oluştuğu görülmektedir (Res. 5). En alt tabaka kırmızı renkli bir harç tabakasından ${ }^{5}$, ikinci katman yoğun mıcırdan, üçüncü katman agregalı bir harçtan oluşmaktadır. Bunların üstünde sırasıyla statumen, rudus, yatak harcı ve opus sectile katmanı yer alır. İkinci evrede, bema ve apsisin kesiştikleri noktada kuzey-güney doğrultusunda, $170 \mathrm{~cm}$ uzunlukta, synthronon basamakları

5 İlk evre tessellatum tabakası, sarı renkli kumsu kapıdaki bir harçla kaplanmıştır. Bu harç katmanı çok ince olması sebebiyle bir katman olarak değerlendirilmemiştir. 
eklenmiştir. Birinci evrenin apsis ve bema mozaikleri içerik ve şekil açısından birbirinden ayrılmaktadır. Bundan dolayı zemin mozaikleri, "Bema Zemin Mozaiği” ve "Apsis Zemin Mozaiğì" adı altındaki iki başlıkta incelenmiştir.
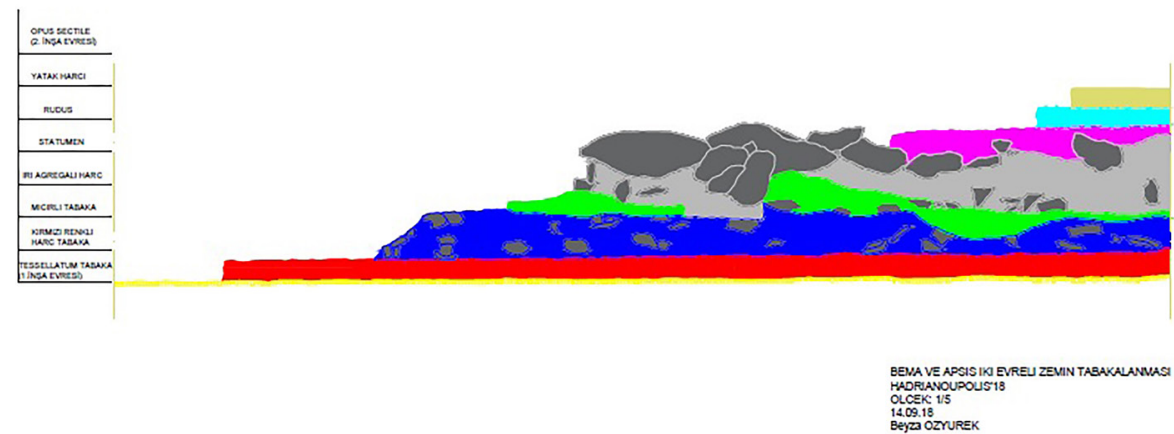

\section{Bema Zemin Mozaiği}

İlk Evre: İlk inşa evresine ait bemanın kuzey ve güney kenarları, ikinci inşa evresinin orta nef zemini ile templon stylobatının altında kalmasından dolayı görülememektedir. Ortaya çıkarılan bema zemin mozaiği 5.61 x $2.66 \mathrm{~m}$ ölçülerinde olup, mevcut kalıntılar ve yapılan hesaplamalara göre, olması gereken ölçüleri 6.50 x 2.70 metredir $^{6}$ (Res. 6). Panel kuzeyden güneye doğru hafif daralmaktadır; kuzeydeki genişlik $2.40 \mathrm{~m}$, güneyde ise 2.66 metredir.
Resim 5

İki İnşa Evresi Zemini Arasındaki Tabaka (Kazı Arşivi).
Resim 6

Kuzeybatı Nekropol Kilisesi Bema ve Apsis Rölövesi (Kazı Arşivi).

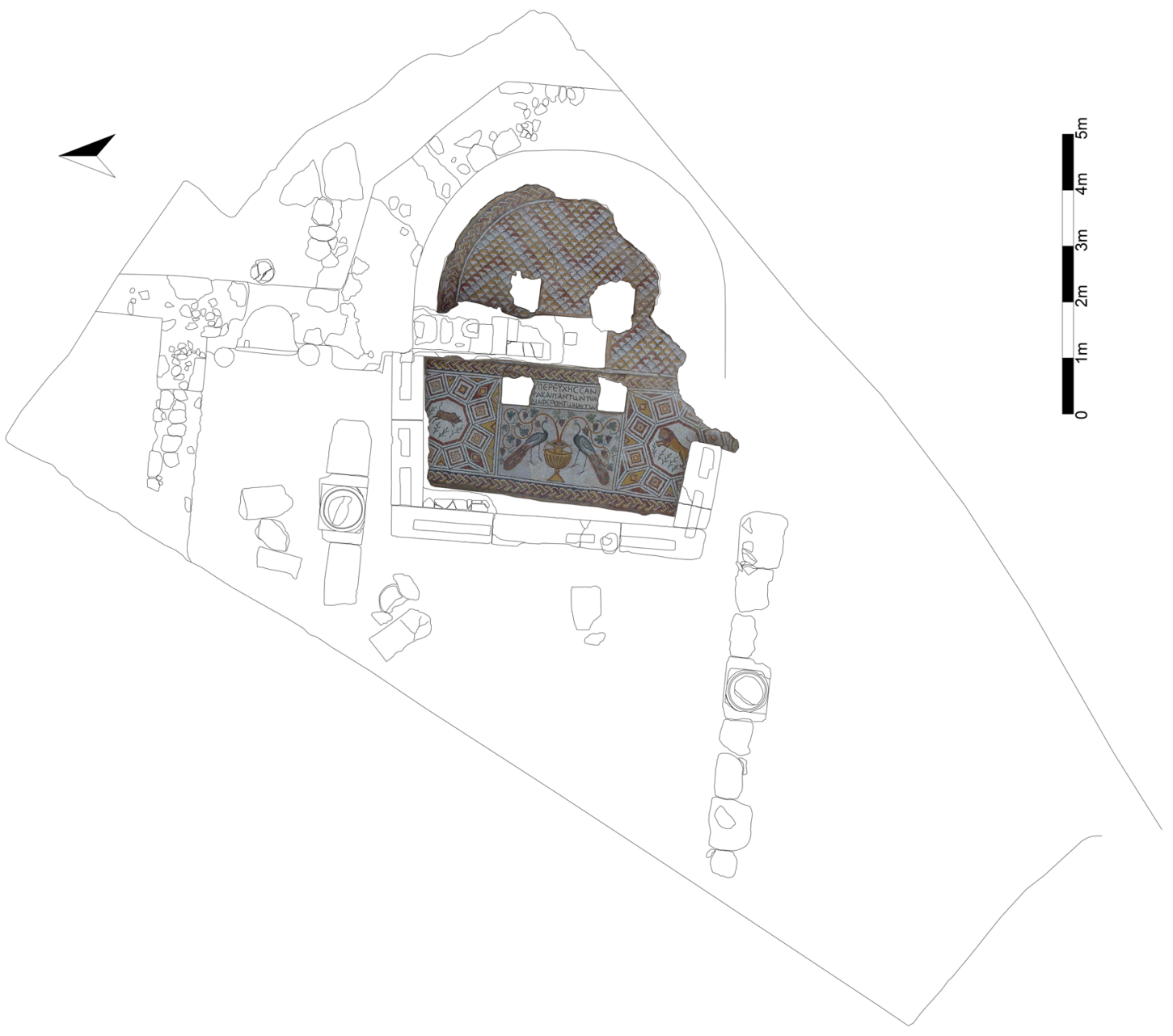

6 Sunulan ölçüler en uzun ve en geniş noktalar arasında alınan mesafelerdir. 
Resim 7

Bema İlk Evre Zemini Genel Görünüm (Kazı Arşivi).
Bema zemin mozaiği, tek panel ve bu panelde yer alan üç panodan ibarettir (Res. 7). Panel, dört yönden siyah-gri zemin üzerine giyoş (Décor I: pl. 72d) motifinin işlendiği, toplam $30 \mathrm{~cm}$ kalınlıktaki çok renkli bordürle çevrelenmiştir7. İkiüç sıra beyaz renkli tesseraların yan yan dizilmesiyle oluşturulmuş, 4-6 cm genişliğindeki şerit, bordürün doğu konturunu oluşturmaktadır. Bu şerit aynı zamanda panelin içindeki panoların doğu ve batı sınırını oluşturmaktadır. Bordürün batı kenarını ise turuncu renkli traverten tesseralardan oluşan, çok az kısmı görülebilen şerit sınırlamaktadır. Bu bordürün, panelin doğu ve batı kenarlarında neredeyse tamamı, güney kenarda ise çok az bir kısmı görülebilmektedir. Kuzey kenarı ise templon stylobatı altında kalmasından dolayı görülememektedir. Bordürün içindeki $7 \mathrm{~cm}$ kalınlıktaki halatlar açık sarı, altın sarısı ve vişne çürüğü renkli tesseralardan oluşmaktadır. Halatların konturları tek sıra siyah ve beyaz tesseraların dizilimiyle oluşturulmuş çizgilerle belirlenerek ışık - gölge kontrastı vurgulanmaya çalışılmıştır.

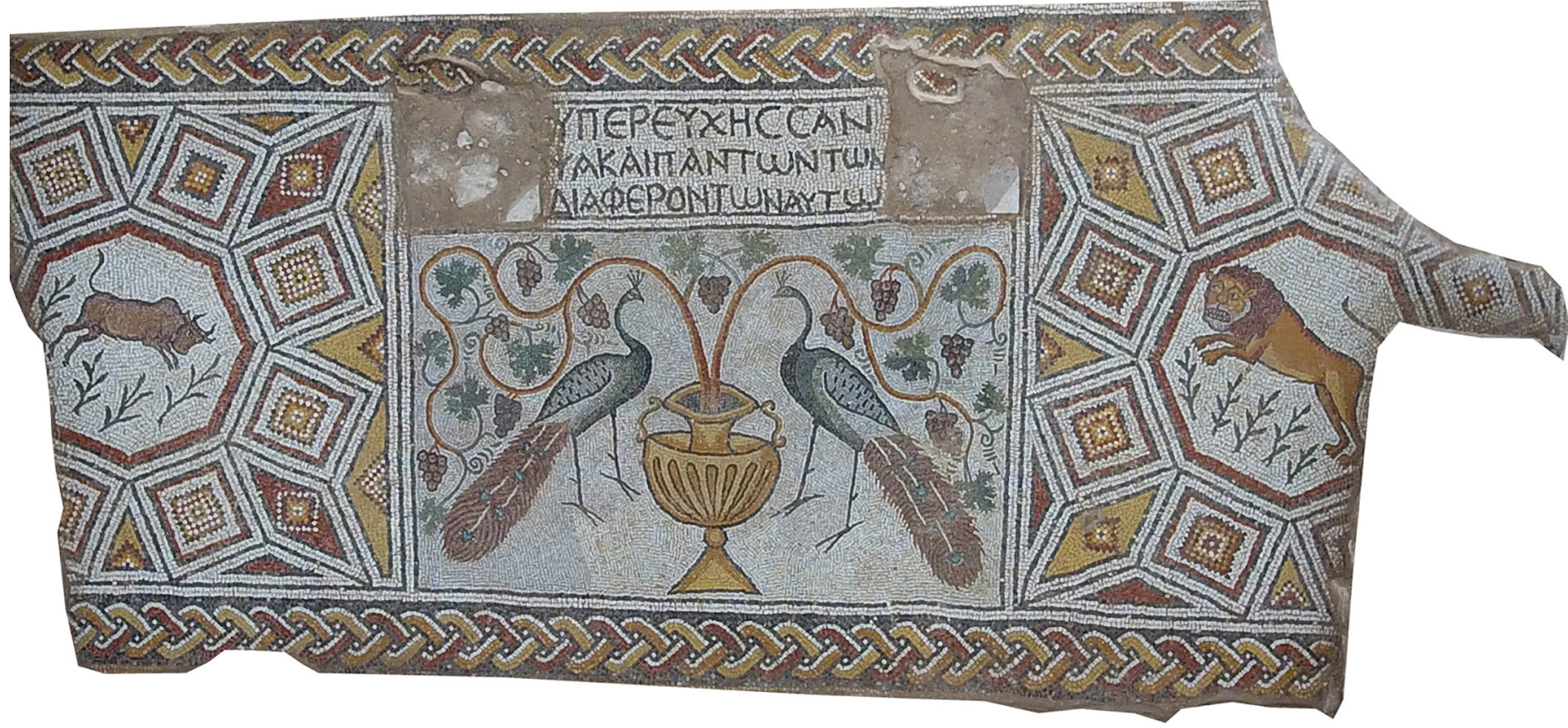

Bema ile apsisin birleştiği bölümde 125 x $45 \mathrm{~cm}$ ölçülerinde bir vakıf yazıtı yer alır (Res. 8). Beyaz zemin üzerine koyu gri-siyah renkte Grek harfleriyle yazılmış, üç satırdan oluşan yazıtın, her satırı ortalama $10 \mathrm{~cm}$ yüksekliktedir. $\mathrm{Bu}$ yazıtın trankripsiyonu şu şekildedir:

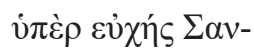

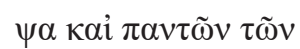

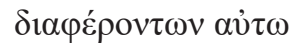

$$
\begin{aligned}
& \text { Sanpsa'nın ve } \\
& \text { tüm ona ait olanlartn } \\
& \text { selameti için }{ }^{8}
\end{aligned}
$$

7 Bordürün kalınlığı, farklı noktalarda 29-33 cm arasında değișmektedir, ortalama $30 \mathrm{~cm}$ kalınlıkta olduğu söylenebilir.

8 Yazııın çevirisini gerçekleştiren Prof. Dr. Mustafa Hamdi SAYAR'a teşekkür ederiz. 


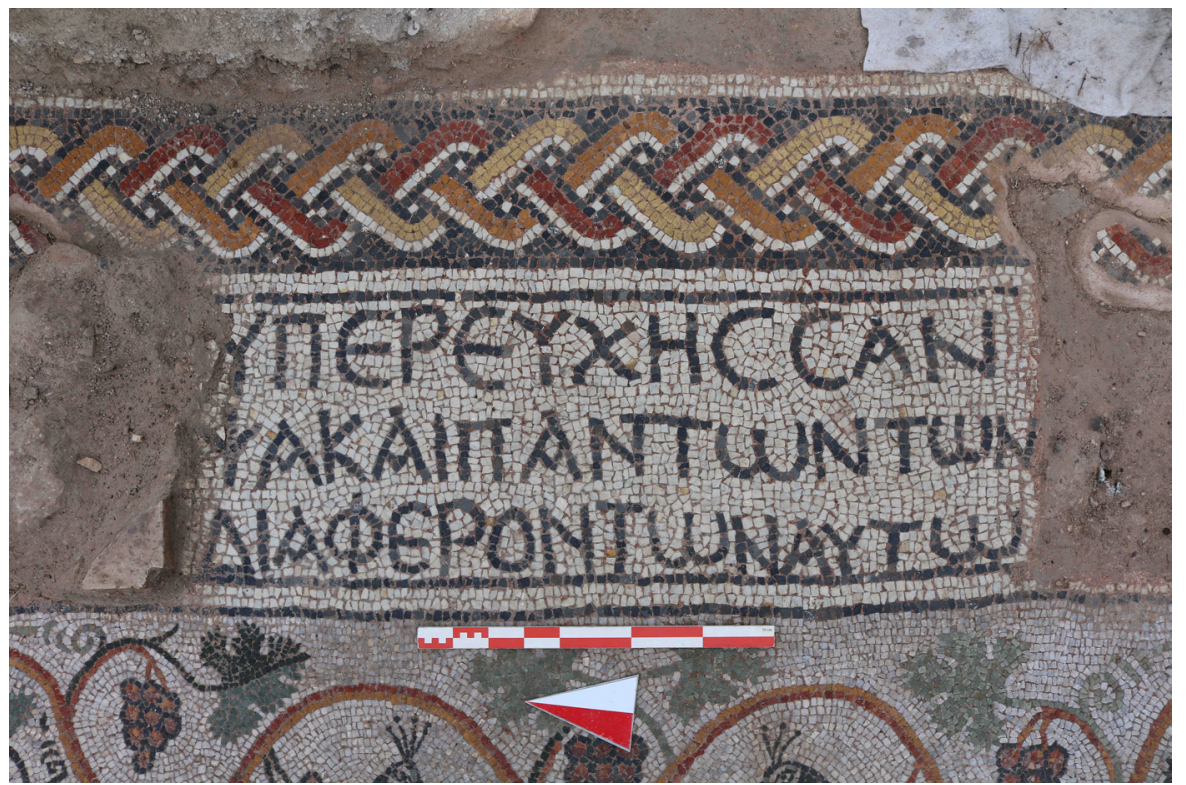

Yazıttan Sanpsa isimli bir şahsın ailesinin selameti için mozaikleri yaptırdı̆̆ anlaşılmaktadır. Benzer bir yazıt Dört Nehir Kilisesi'nin mozaik zemininde de yer almaktadır. Yazıtta "Sadı Scholarios Himerios ve onurlu ve saygın Valentina'nın yeminine/adağına göre" ifadeleri geçmektedir (Lafl1 - Christof 2012: 45). Yazıttan anlaşıldığı kadarıyla Dört Nehir Kilisesi'ndeki zemin mozaiklerini ismi geçen şahısların yaptırdığı anlaşılmaktadır. Her iki kilisede benzer şekilde adak yazıtlarının olması Hadrianoupolis'in Erken Bizans döneminde bir gelenek olarak kentin önde gelenleri tarafından kiliselerin mozaiklerinin yaptırıldığg ya da kiliselere hizmet için çalışan vakıfların varlıklı kişiler aracılığıyla kiliselere bağışta bulundukları ihtimallerini doğurmaktadır. Kuzeybatı Nekropol Kilisesi'ndeki yazıtın karakter özellikleri İS 5.-6. yüzyı1 aralığını işaret etmektedir.

Bema panelinin ortasındaki tavus kuşu figürlü, refrigerium sahnesinin işlendiği pano, $220 \times 130 \mathrm{~cm}$ ölçülerindedir (Res. 9). Panonun zemini beyaz renkli
Resim 8

Bema ile Apsisin Birleştiği Bölümdeki Adak Yazıtı (Kazı Arşivi).

Resim 9

Tavus Kuşu Figürlü Refrigerium Sahnesinin İşlendiği Pano (Kazı Arşivi).

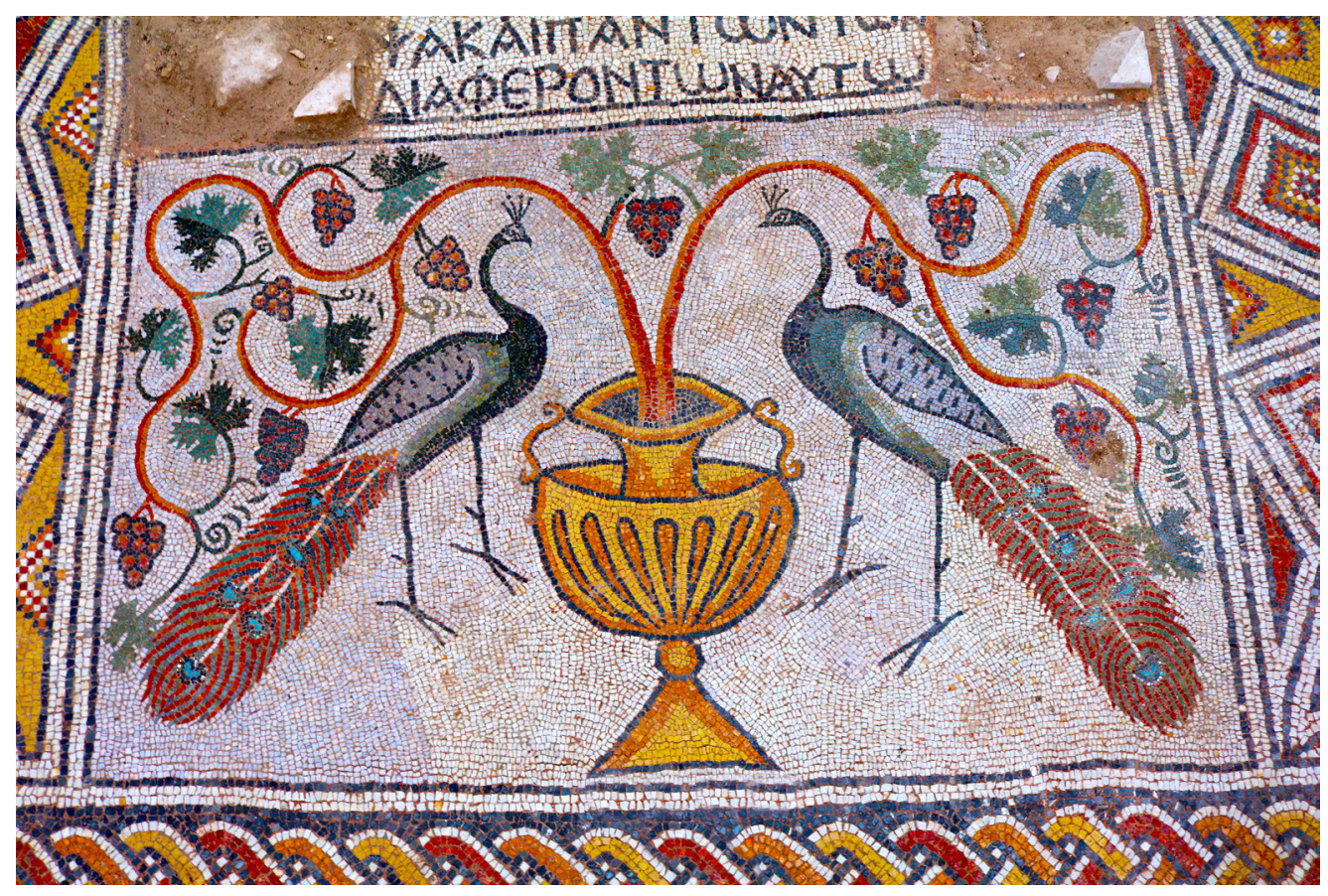


tesseralardan oluşur, merkezinde üzüm bağının filizlendiği çift kulplu krater yer alır ${ }^{9}$. Bunun iki yanında antitetik yerleştirilmiş, durağan tasvir edilmiş tavus kuşu figürleri görülür ${ }^{10}$. Bizans ve Hristiyan ikonografisinde; panonun merkezindeki krater biçimli kap, kutsal suyun çıktığ 1 veya bulunduğu çeşmeleri, bundan çıkan üzüm, İsa'nın kanı ve komünyondaki (ökaristi ayini) şarabı sembolize eder (Ferguson 1961: 31-32; Anđelković vd. 2010: 231-248). Refrigerium sahnesi ve tavus kuşu figürü, Geç Antik Çağ ve Bizans Dönemi’ne ait resim örneklerinde sıklıkla uygulanmıştır. Tavus kuşunun öldükten sonra etinin geç çürümesi hem Roma hem de Bizans Dönemi'nde ölümsüzlükle ilişkilendirilmesine sebebiyet vermiştir. Tüylerinin dökülmesinin sonra, daha parlak ve güzel biçimde yeniden çıkması ise yeniden dirilişin (doğuşun) sembolü olmuştur. Kuyruğunun kapanmasının ardından oluşan göz şekli, gökyüzündeki yıldızlar, her şeyi gören Tanrı ve kilisenin sembolüdür. Eden Bahçesi'nde (cennet bahçesi) yer alan kuşlardan olan tavus kuşu, genel olarak yeniden diriliş, ölümsüzlük ve iyi ruhların sembolüdür (Ferguson 1961: 42; Parman 1993: 387-412; Gilhus 2006: 103; Anđelković vd. 2010: 233-240; Karademir 2019: 216-217). Tavus kuşlarının olduğu kompozisyonu sanatsal açıdan da incelemek gerekmektedir. Anatomik açıdan incelendiğinde tavus kuşlarının görkemli kuyruklarının varlığı nedeniyle erkek oldukları anlaşılmaktadır. Figürlerin anatomik orantılarının genel anlamda başarılı olduğunu söylemek gerekir. Kuşların baş, boyun bölümleri profilden, göğüs ve bacaklar $13 / 4$ oranında cepheden, kuyrukları ise tam cepheden verilmiştir. Bacaklardan biri önde diğeri arkada verilmiş, arkadaki bacak kısa öndeki bacak daha uzun işlenerek sahneye derinlik verilmeye çalışılmıştır. Tavus kuşları ile kraterin bulunduğu sahne kapalı kompozisyona sahiptir. Kare örüntü içerisinde kompoze edilen sahne devam ediyormuş hissine sahip değildir. Kompozisyon, kare örüntünün ortasına eşit mesafede ve boşlukta yerleştirilmiştir. Belirli bir düzende ve kapalı kompozisyon olan kurgu genelde dönemin edebi ve dini hikâyelerini içeren çalışmalarda belli bir düzende yer almaktadır. $\mathrm{Bu}$ aynı zamanda bir örüntü kompozisyonudur ve sembolik değerlerle zemine yerleştirilmiştir. Sahnedeki objelerin ve tavus kuşlarının çizgisel organizasyonu yatay kurgulanmıştır. Bakıldığında sahne yatay yönde ilerlemekte olup, izleyici ilk baktığında tavus kuşlarının görülmesi sağlanmıştır. Bu durum için de kompozisyon renk ve gölgelendirme ile desteklenmiştir. Simetrik dengeye sahip sahne çizgisel desen prensibi çerçevesinde biçimlendirilmiş ve izleyiciye hazır verilmiştir. Böylelikle sahne izleyiciye doğrudan gösterilmiştir. Kompozisyonda renk çok etkileyici şekilde sunulmuştur. Fizyolojik ve psikolojik olarak kırmızı, sarı, mavi, gri, turuncu, yeşil, pembe, vişne çürüğü renkleri genel olarak gözlemlenebilen renklerdir. Kırmızı, sarı ve mavi gibi ana renklerin hepsi mevcut olup, ara renklerden de turuncu ve yeşil kullanılmıştır. Nötr renk olarak da gri, beyaz ve siyah görülmektedir. Analog renk armonisi mevcuttur; sar1turuncu ve mavi-yeşil yan yana kullanılmıştır. Kuyrukta kırmızı, yeşil, mavi ve turuncudan oluşan dörtlü renk armonisi mevcuttur. Monokrom renk armonisi de vazoda ve tavus kuşu gövdesinde işlenmeye çalışılmıştır. Kompozisyonu oluşturan tavus kuşlarında, kraterde, sarmaşık dalı ve yapraklarında ışık gölge uyumu verilmek istenmiştir. Bir rengin açı ve koyu değerleri modle edilmiştir. Aynı zamanda farklı tonda renklere sahip unsurlarda da modülasyon değeri de görülmektedir. Kendi 1şık değerleriyle de kromatiktir, rengin kendi 1şığından faydalanılmıştır. Tüm kompozisyondaki 1şık-gölge dengesi incelendiğinde,

9 Kraterde açık ve koyu sarı, siyah, bağın dallarında sarı, vişne çürüğü ve siyah, yapraklarda açık ve koyu yeşil, üzümlerde sarı, turuncu, kırmızı, vişne çürüğü, pembe ve siyah renkli tesseralar kullanılmıştır.

10 Tavus kuşunun boyun, göğüs, sırt ve ayaklarında koyu gri ve siyah, kanatlarında gri, beyaz, siyah ve yeşil, kuyruğunda mavi, firuze, vişne çürügü, kırmızı, sarı, beyaz, yeşil ve turuncu renkli tesseralar kullanılmıştır. 
1şığın karşıdan geldiği anlaşılmaktadır. Gölge ile 1şık dengesi sahnede en bariz şekilde asma yapraklarında işlenmiştir. Sahnenin solundaki asma yaprakları ikiye bölünerek siyah ve yeşil renklerle, sahnenin sağındaki asma yaprakları ise yeşil ve mavi renklerle ikiye bölünerek gölge-1şık oyunu gösterilmiştir. Sahnede dikkat çeken bir sanatsal özellik de tüm figüratif unsurların hacimli gösterilmiş olmasıdır. Örneğin kraterin kaidesinde ve gövdesinde orta kısım sarı, kenarları turuncu verilerek kabın dairesel hacmi işlenmiştir. Aynı uygulamayı asma dallarında da görmek mümkündür. Dalların yarısı kahverengiye yakın vişne çürüğü, yarısı ise turuncu renkte verilerek dalların dairesel kesitli bir hacme sahip olduğu izleyiciye vurgulanmak istenmiştir. Genel anlamda bakıldığında ise sahnede mekân olgusunun olmadığı görülmektedir. Figürlerde zeminmekân ilişsisi kurgulanmamıştır. Tavus kuşları havada gibi durmaktadırlar. Kompozisyonda dikkat çeken bir diğer husus ise sahnenin sağ ve sol tarafinda detayların birbirinden farklı olmasıdır. Sahnede ilk bakışta bir simetri var gibi görünse de detaylar sahnede tam bir simetri olmadığını ortaya koymaktadır. Sahneyi kraterin tam ortasından sağ ve sol olmak üzere ikiye ayırıp incelemek gerekmektedir. Sahnenin sağındaki tavus kuşu soldakine göre daha hacimlidir. Sağdaki tavus kuşunun bacakları ve kuyruğu soldakine göre daha uzundur. Sağdaki kuşun başındaki sorgucunun üçlü, soldakinin ise dörtlü olduğu görülmektedir. Sağdaki kuşun gagası düz, soldaki ise kanca formundadır. Sağdaki kuşun kanatlarının bitiminden göğse kadar olan bölümde beyaz, açık yeşil, mavi ve siyah olmak üzere dört renk; soldakinde ise beyaz, açık yeşil ve siyah olmak üzere üç renk kullanılmıştır. Ayrıca sağdaki kuşların kuyrukları hem renk hem de form olarak birbirinden hafif farklılıklar içermektedir. Sahnenin sağ tarafındaki asma yaprakları ile sol taraftaki asma yaprakları da birbirinden farklılıklara sahiptir. Soldaki asma yaprakları tam ortadan ikiye ayrılarak siyah ve mavi renklerden; sağdaki asma yaprakları da tam ortadan ikiye ayrılarak mavi ve yeşil renklerden oluşmaktadır. Sağ bölümdeki üzüm salkımları sol bölümdeki üzüm salkımlarına göre daha hacimlidir. Asma dallarına dikkatli bakıldığında ise sağ ve sol bölümün tam simetri olmadığ 1 da anlaşılmaktadır. Son olarak ise soldaki tavus kuşunun sağ ayağının bitiminden itibaren beyaz renkli zeminde ton farklılığ gözlemlenmektedir. Bu durum sahnede kullanılan beyaz renkli tesseraların farklı dere yataklarından, ocaklardan elde edilmiş olmasıyla ya da daha sonraki bir tadilat çalışmasıyla açıklanabilir. Sahnedeki tüm bu farklılıklar iki olasılığı ortaya çıkarmaktadır. İlk olasılık sahnenin sağ ve sol bölümünün farklı sanatçılar tarafından yapılmış olması; ikinci olasılık ise farklılıklarla kompozisyona hareketlilik kazandırılmak istenmiş olmasıdır.

Panelin kuzeyindeki boğa figürlü pano 132 x $170 \mathrm{~cm}$ ölçülerindedir; ama olması gereken ölçüsü 195 x 170 cm'dir (Res. 10). Kuzey yarısı büyük oranda templon stylobatının altında kalmıştır. Panonun merkezinde, kenarları $37 \mathrm{~cm}$ uzunlukta, konturu ikişer sıra vişne çürüğü ve beyaz renkli tesseraların dizili ile oluşturulmuş iki şeritle belirlenmiş bir sekizgen yer alır ${ }^{11}$ (Décor II: pl.373a). Sekizgenin içerisinde, beyaz zeminli ve bitkisel dekorlu kurgusal bir alanda, saldırı (şahlanmış ya da koşar) pozisyonunda gösterilmiş boğa figürüne yer verilmiştir ${ }^{12}$. Bu sekizgen kare, dikdörtgen, eşkenar dörtgen ve üçgen gibi çok renkli geometrik şekillerle çevrilmiştir ${ }^{13}$. Panoda kalan boşluklar, farklı ölçü

$11 \mathrm{Bu}$ iki şerit, tek sıra tesseraların dizilimi ile oluşturulan siyah-koyu gri renkli bir çizgiyle birbirinden ayrılmıştır.

12 Bitkilerin hepsi yeşil ve tonlarındaki tesseralardan oluşur. Boğa figüründe ise siyah, vişne çürüğü, kırmızı, sarı, turuncu ve beyaz renkli tesseralar kullanılmıştır.

13 Kareye benzer dikdörtgenler 35 x 99 cm, 35 x 38 cm ölçülerindedir. Karelerin kenar uzunlukları 38 ve 39 santimetredir. Eşkenar dörtgenlerin kenar uzunlukları $39 \mathrm{~cm}$, toplam uzunluğu 72 santimetredir. Kare ve dikdörtgen zemini beyaz, bunların ortasında yer alan karelerin zemini ise sarı renklidir. 
Resim 10

Boğa Figürlü Pano (Kazı Arşivi).

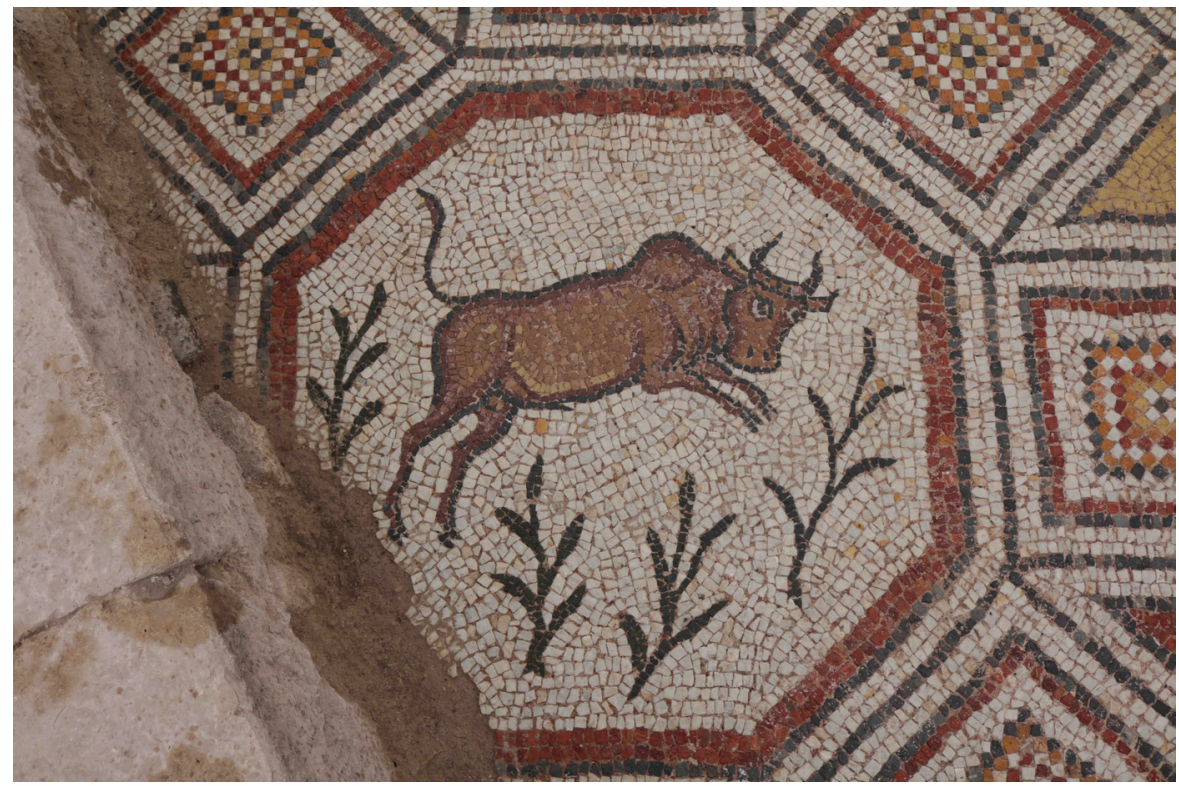

ve renkteki üçgen motifleriyle doldurulmuştur ${ }^{14}$. Boşlukları dolduran üçgenler, aslında sekizgeni çevreleyen kare, dikdörtgen ve eşkenar dörtgenin yarım kalmış halleridir. İçlerinde yer alan, yarım kalmış haç ve kare motifleri de buna işaret eder. Bu hususlar panoların sonsuzluk prensibinde tasarlandığını göstermektedir. Tüm geometrik şekilli motiflerin konturları, beyaz ve siyah renkli çizgilerden oluşan şeritlerle belirlenmiştir. Karelerin merkezinde, ortasına Yunan haçı motifi yerleştirilmiş kareler yer alır ${ }^{15}$. Bunun haricinde, en diş hat ile ortadaki kare motifi arasına, beyaz, vişne çürüğü, siyah renkli çizgi ve şeritlerle, kare şekilleri oluşturulmuştur. Böylece iç içe geçmiş kare motifleri oluşturulmuştur. Benzer husus dikdörtgen ve eşkenar dörtgen için de geçerlidir. Panonun esas figürü olan boğanın uzuvlarının orantı uyumu konusuna özen gösterilmiştir. Sahnede işlenen bitki detayları nedeniyle doğada olduğu anlaşılan boğa saldırı halinde ya da koşarken verilmiştir. Başını hafif aşağıya doğru eğerek koşmaktan ziyade saldırı anında olduğu hissettirmektedir. Boğanın vücudu profilden, baş1 ise 3/4 oranında cepheden verilmiştir. Ön bacaklarını öne doğru atarak hamle yapmış, arka bacaklarını yere tam basarak ileri doğru atılmıştır. Bacakların perspektif anlayışıyla resmedilmiş olmasıyla sahnede derinlik az da olsa sağlanmıştır. Gözler daire formunda ve yüze göre iridir. Burun iki adet siyah renkli tessera ile gösterilmiş, ağzı ise gösterilmemiştir. Yüzünün yarısı daha koyu tessera ile resmedilerek gölge-1şık kontrastı oluşturulmuştur. Ön bacakların hafif göğse doğru çekilerek öne doğru uzatmasıyla göğüs üzerinde oluşan kas hatları yay şeklindedir. Ense bölümü iri bir yumru şeklinde olan figürün kahverengi renkli tesseralarla yapılmış karnı da yay şeklinde olup, alt kısma işlenen bir sıra sarı renkli tessera ile bu bölüm hacimlendirilmeye çalışılmıştır. Karın ile arka bacaklarının birleşme noktasında erkeklik uzvu görülmektedir. Arka bacaklarının gövdeyi ileri itmeye yönelik olarak yerden güç almasıyla kalça bölümünde açık kahverengi renkli kas hattı ortaya çıkmıştır. Kuyruğunu "S"

Eşkenar dörtgenlerin zemini vişne çürüğü, ortasındaki karelerin zemini ise sarı renklidir.

14 Üçgenlerin zemini sarı renklidir. Alt kısımlarında, kare ve dikdörtgenlerin içindeki kare motiflerine renk ve şekil açısından benzeyen, ancak bunların yarım kalmış halleri şeklinde ele alınmış, üçgenlere yer verilmiştir.

15 Kare ve dikdörtgenlerin merkezindeki haçların kolları 4,5 santimetredir. Renk açısından birbirinden farklı düzenlenmişlerdir. Bütün haçların merkezinde siyah ve beyaz renkli tek bir tessera yer alır. Ortasında siyah renkli tessera olan haçın kolları beyaz, beyaz renkli olanın kolları ise siyah renkli tek bir tesseradan oluşur. 
yaparak yukarı doğru uzatmıştır. Kuyruğun bitim noktasındaki damla formlu tüylü uç, kahverengi renkli tesseralardan oluşur. Sekizgen geometrik pano içerisinde kompoze edilen figür; devam ediyormuş hissine sahip değildir. Boğa sanki hareket halindeyken tıpkı bir fotoğraf karesi gibi anlık dondurulmuş gibi kompoze edilmiştir. Kompozisyon sekizgen örüntünün ortasında eşit mesafede ve boşlukta yerleştirilmiştir. Kurgu belirli bir düzende ve kapalı kompozisyondur. Kompozisyonda coğrafyaya ait olduğu düşünülen yeşillik, bitkiler boğanın etrafında ayaklarının altına gelen kısımda yer almaktadır. Solda bir adet, sağda üç adet olmak üzere dört adet bitki yerleştirilmiştir. Zemin ile ilgili bilgi veren tek şey bitkilerdir; onun dişında zeminde herhangi bir gölge vb. kurgulanmamış ve modle edilmemiştir. Yüzeyin çizgisel organizasyonu yatay kurgulanmıştır. Bakıldığında figür yatay yönde ilerler ve izleyicinin ilk görmesini istediği boğanın sağa gidiş hareketidir. Bu durum renk, gölgelendirme, anlık olma hareketiyle ve jest ile desteklenmiştir. Boğa kompozisyonunun formu kapalı, çizgisel desen prensibi çerçevesinde biçimlenmiş, izleyiciye hazır bir şekilde sunulmuştur. Merkeze konuşlanmış asimetrik bitkilerle desteklenmiş bir denge algısı sunulmuştur. Boğa kompozisyonunda turuncu, kırmızı, yeşil, beyaz ve toprak tonlarında krem renkleri genel olarak gözlemlenebilen renklerdir. Ana renklerden sadece kırmızı, ara renklerden ise sadece yeşil kullanılmıştır. Kompozisyonda 1şık ve gölge dengesi vurgulanmıştır. Bir rengin açık ve koyu değerleri modle edilmesi amaçlanmıştır. Aynı zamanda farklı tonda kontur çizgileri oluşturularak modülasyon değerleri de görülebilmektedir. Kendi 1şık değerleriyle de kromatiktir, yani rengin kendi 1şı̆̆ından faydalanılmıştır. Kompozisyonda 1şık karşıdan gelmektedir.

Panelin güneyindeki aslan figürlü pano (Décor II: pl.373a) 195 x $185 \mathrm{~cm}$ ölçülerindedir (Res. 11). Kuzey yarısı sağlamdır, ancak güney yarısı templon stylobatının altında kalmasından dolayı büyük oranda tahrip olmuştur. Boğa

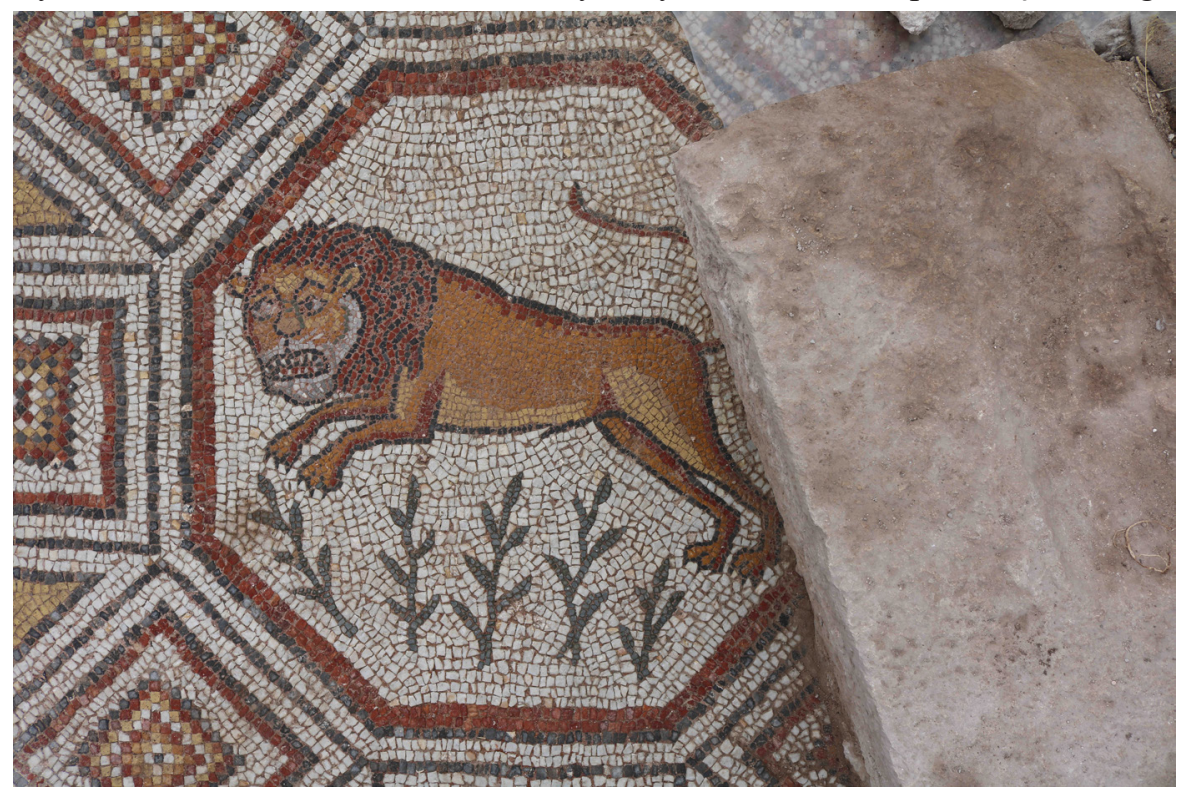

figürlü panoya göre daha büyük boyutlu ele alınmıştır. Dekorasyon açısından boğa figürlü pano ile benzerdir, ancak daha büyük boyutlu olmasından dolayı içerisindeki geometrik şekilli motiflerin ölçülerinde birtakım farklılıklar görülür. Bir diğer farklılık ise güney panodaki eşkenar dörtgen zemininin vişne çürüğü, bu panodaki eşkenar dörtgen zemininin ise sarı renkli olmasıdır. Panonun merkezindeki sekizgenin içerisinde, beyaz zeminli ve bitkisel dekorlu kurgusal bir alanda, saldırı (şahlanmış) pozisyonunda gösterilmiş aslan figürüne yer
Resim 11

Aslan Figürlü Pano (Kazı Arșivi). 
verilmiştir. Aslanın vücudu profilden başı ise $3 / 4$ oranında cepheden verilmiştir. Ön bacakları ileri atılır vaziyette, arka bacakları yere tam basar durumda gösterilen aslan saldırı pozisyonundadır. Bacakların işleniş biçimi perspektif anlayışı içerisindedir. Gözler elips formda, kaşlar çatıktır. Keskin olduğu izlenimi veren üçgenimsi dişlere sahip aslanın ağzı açık, kükrer şekildedir. Sakalı beyaz ve gri tesseralardan meydana gelir. Yanaklardaki turuncu renkli tesseraların farklı tonları işlenerek, gölge-1ş1k kontrastı oluşturulmuştur. Yeleleri dalgalı gösterilen aslanın erkek olduğu anlaşılmaktadır. Aslanın karın kısmı hafif yay çizmektedir. Aslanın tüm gövdesi turuncu renkli tessaralardan oluşmaktadır. Fakat karnın alt kısmı ile arka sol bacağın bir bölümü sarı renkli tesseralarla yapılarak bu bölümlere hacim kazandırılmıştır. Karın ile arka bacaklar arasında, tek sıra siyah renkli erkeklik uzvu gösterilmiştir. Kuyruğunu havaya doğru "S" şeklinde kaldırarak belinin ortasına kadar uzatmıştır. Aslan figürünün kompozisyonu ve kurgusu boğa ile neredeyse bire bir aynıdır. Tıpkı boğada olduğu gibi kapalı kompozisyona sahiptir. Sekizgen panel içerisinde kompoze edilen aslan, devam ediyormuş hissine sahip değildir. Aslan sanki hareket halindeyken tıpkı bir fotoğraf karesi şeklinde anda dondurulmuş gibi kompoze edilmiştir. Ayrıca aslan kızgın bir şekilde avına saldırıyor gibi bir andadır. Kompozisyon sekizgenin ortasına eşit mesafede ve boşlukta yerleştirilmiştir. Kompozisyonda coğrafyaya ait olduğu düşünülen yeşillik, bitkiler aslanın etrafında ayaklarının altına gelen kısımda yer almaktadır. Bitki sayıları boğa kompozisyonunda olduğu gibi dört adettir. Aslanda da zemin ile ilgili bilgi veren tek şey bitkilerdir. Onun dışında zeminde herhangi bir gölge vb. kurgulanmamış ve modle edilmemiştir. Aslan kompozisyonunun yüzeyinin çizgisel organizasyonu yatay yönde kurgulanmıştır. Bakıldığında figür yatay yönde ilerler ve izleyicinin ilk görmesini istediği aslanın sola yöneliş (saldırı anındaki yönelme) hareketidir. Bu durum renk, gölgelendirme, anlık hareketiyle ve jest ile desteklenmiştir. Aslan dişlerini gürler pozisyonda gibi açıp dişlerini göstermiştir. Kompozisyonun dengesi ve formu kapalıdır. Merkeze konuşlanmış asimetrik bitkilerle bir denge algısı verilmek istenmiştir. Kompozisyonda bitkilerin hepsi yeşil ve tonlarındaki tesseralardan; aslanın gövde, göğüs, sırt, ayakları ve kuyruğu altın sarısı, açık sarı, vişne çürüğü ve siyah, yelesi vişne çürüğü ve siyah, baş kısmı beyaz, gri, altın sarısı, açık sarı, vişne çürüğü ve siyah, pençeleri siyah ve dişleri beyaz renkli tesseralardan oluşturulmuştur. Ana renklerden kırmızı, ara renklerden yeşil kullanılmıştır. Kompozisyonda ş̧ık ve gölge uyumu vurgulanmak istenmiştir. Bir rengin açık ve koyu değerleri modle edilmeye çalışılmışırı. Aynı zamanda farklı tonda tesseralarla da kontur çizgileri oluşturularak modülasyon değerleri de görülebilmektedir. Iş̧ı, boğa kompozisyonundaki gibi karşıdan gelmektedir.

Kuzey paneldeki boğa figürü, Hristiyan ve Bizans sanatında güç, barış, koruyuculuk ve yeniden dirilişi sembolize eder. Aynı zamanda İncil yazarlarından Lucas'1n sembolüdür (Audsley - Audsley 1865: 102; Clement 1886: 190; Ferguson 1961: 22; Gilhus 2006: 104-107; Simitopoulou vd. 2015: 222-223) Aslan ise yeniden diriliş, güç, Hz. İsa ve Marcus'un sembolüdür (Audsley 1865: 40, 87, 102; Clement 1886: 219; Ferguson 1961: 21) Bema paneline uzaktan bakıldığında aslan ve boğanın özel birer pano içerisinde betimlenmesi ve bunların çevresinde başka bir figür görülmemesi, ilk olarak İncil yazarlarından Marcus ve Lucas'ın sembolize ettiklerini düşündürmektedir. Bununla birlikte Hristiyan sanatında, Marcus ve Lucas'ın kanatlı gösterildiği, kutsal kitap veya ruloyla betimlendiği bilinir (Audsley 1865: 97; Ferguson 1961: 21-22) Sadece Ravenna San Vitale Kilisesi (İS 545-549 tarihlerindeki mozaikleri) bemasının kuzey ve güney duvarındaki, "İncil Yazarları" sahnesinde, kanatsız ve kitap-ruloyla betimlenmeyen aslan ve boğa figürleri görülür (Deliyannis 2010: 237-246). 
Bununla birlikte bu sahnenin alt kısmında İncil yazarlarının personifikasyonları yer alır. Dolayısıyla şu ana kadar yapılan araştırmalara göre İncil yazarlarını sembolize eden aslan ve boğanın, kanatsız ve kutsal metin olmadan resmedilmiş örneğine pek rastlanılmamıştır. Bu şekilde yapılan örnekler daha çok günlük yaşam veya hayvan mücadelesi sahnelerinde görülür. Kuzeybatı Nekropol Kilisesi bema panelindeki aslan ve boğanın birbirine yönelmiş olması, her ikisinin saldırı pozisyonunda gösterilmesi, bu sahnede hayvan mücadelesi konusunun işlendiğini düşündürmektedir, ancak her iki hayvan da ayrı kurgusal mekânlarda betimlenmiştir. Ayrıca iki pano arasında tavus kuşu figürlü pano da yer alır. Aslan ve boğa figürünün birlikte kurgulandığı bir kompozisyon Heraclea Lyncestis'te yer alan Episcopal Bazilika'da karşımıza çıkmaktadır (Dimitrova 2015: fig. 3). Kompozisyonda aslan ve boğa birbirine doğru hamle yapar gibi görünmektedir. Hayvanların sanatsal özellikleri Kuzeybatı Nekropol Kilisesi örneğiyle büyük benzerlikler göstermektedir. Dimitrova, kiliselerde boğa ve aslan figürlerinin kullanılmasını şöyle ifade etmektedir: "Eski Ahit ayetlerinin kompozisyonlarının illüstrasyonu, Hristiyan kiliselerinde sembolik imgelerle ifade edilmeye başlanmıştır. Hristiyanlıktaki kutsal ayinlerin ölümsüz yaşam verdiğine inanılırdl. Hristiyan toplulukların dünya hayatının son bulacă̆ klyamet çağrlşımları mozaiklerde tasvir edilen sahnelerle ilişkilendirilmiştir. Bir antilopu yiyen panterin alegorik imgesiyle bedensel ölümü simgelemesinin yanında hayatın zaferi, fedakârlık, yeniden diriliş anlamlarını içeren bir zıtlıkta kompozisyon yardımıyla görselleştirilmiştir. Ölümü yenen Dionysos kültüyle ilişkilendirilen asma ve antilop, aslan ve boğa, panterve yaban keçisinin sembolik imge olarak kullanılması katekümenlerin (farklı dinlerden Hristiyanlığa geçen, üç yıllık dini eğitim sonucunda vaftiz edilerek kiliseye girebilen grup/halk) mitoloji konusundaki bilgileriyle ilişkilendirmesini sağlamıştır. Sembolik Hristiyan ikonografisi, pagan kökenli katekümenlere aşina oldukları imgelerle aktarılarak vaftiz, ökaristi ve yeniden diriliş inancının kavranılması sağlanmıştır". Bu ifadelerden anlaşıldığ gibi Kuzeybatı Nekropol Kilisesi bema mozaiğinde ölümsüzlüğün illüstratik ifadesi olan tavus kuşlarının, yeniden dirilişin imgesel ifadesi olan aslan ve boğa işlenmiş olması tesadüf değildir. Kullanılan tüm figürler Hristiyanlık inancındaki öbür dünyada yeniden dirilişi ve ölümsüz olmayı vurgulamaya yönelik olmalıdır. Erken Bizans dönemindeki paganizm figürlerinin sıklıkla görülmesinin sebebi de katekümenlerin Hristiyanlık inancını tam kavramasını sağlamaya yönelik olarak hafızalarındaki paganist imgelerin yardımcı olarak görülmesinden kaynaklanmış olmalıdır.

İkinci Evre: Bemanın ikinci evresine ait zeminin neredeyse tamamı tahrip olmuştur (Res. 12). Bemanın iç kısmında yapılan kazılarda ikinci evreye ait zeminin alt yapısı tıpk1 mozaik zemin döşemesinde olduğu gibi tesviye edilmiştir. İkinci evre zemini aşağıdan yukarıya doğru statumen, rudus, yatak harcı tabakalarından oluşmaktadır. Zemindeki tesviye tabakaları, ikinci evrenin zemininin de mozaikle süslendiğini işaret eden verilerden biridir. İkinci evrenin bema zemin döşemesine dair diğer bir iz ise bemanın kuzeydoğu köşesinde dikdörtgen şekilli bir panonun içerisindeki derz izleridir. Derz izlerine bakıldığında yaklaşık olarak 125 x $135 \mathrm{~cm}$ boyutlarındaki dikdörtgen panonun içerisine 5 sıra yan yana 5 sıra üst üste olmak üzere simetrik şekilde dizilmiş altıgen formlardan oluşan zemin süslemesi yapıldığı anlaşılmaktadır (Res. 13). Ortalama $16 \mathrm{~cm}$ genişliğinde olan altıgen formların plakalarından herhangi bir parça günümüze ulaşmamıştır. Pano içerisindeki sökülmüş olan altıgen plakaların yatak harcındaki yuvalarından anlaşıldığı kadarıyla plakaların kalınlığı 3-4 cm arasında olmalıdır. Altıgen formların yan yana dizilmesiyle birbirini kesen daire formlar oluşturulduğu izlenmektedir. Opus sectile zeminden günümüze bemanın 
Resim 12

Bema İkinci Evre Zemini Genel Görünüm (Kazı Arşivi).

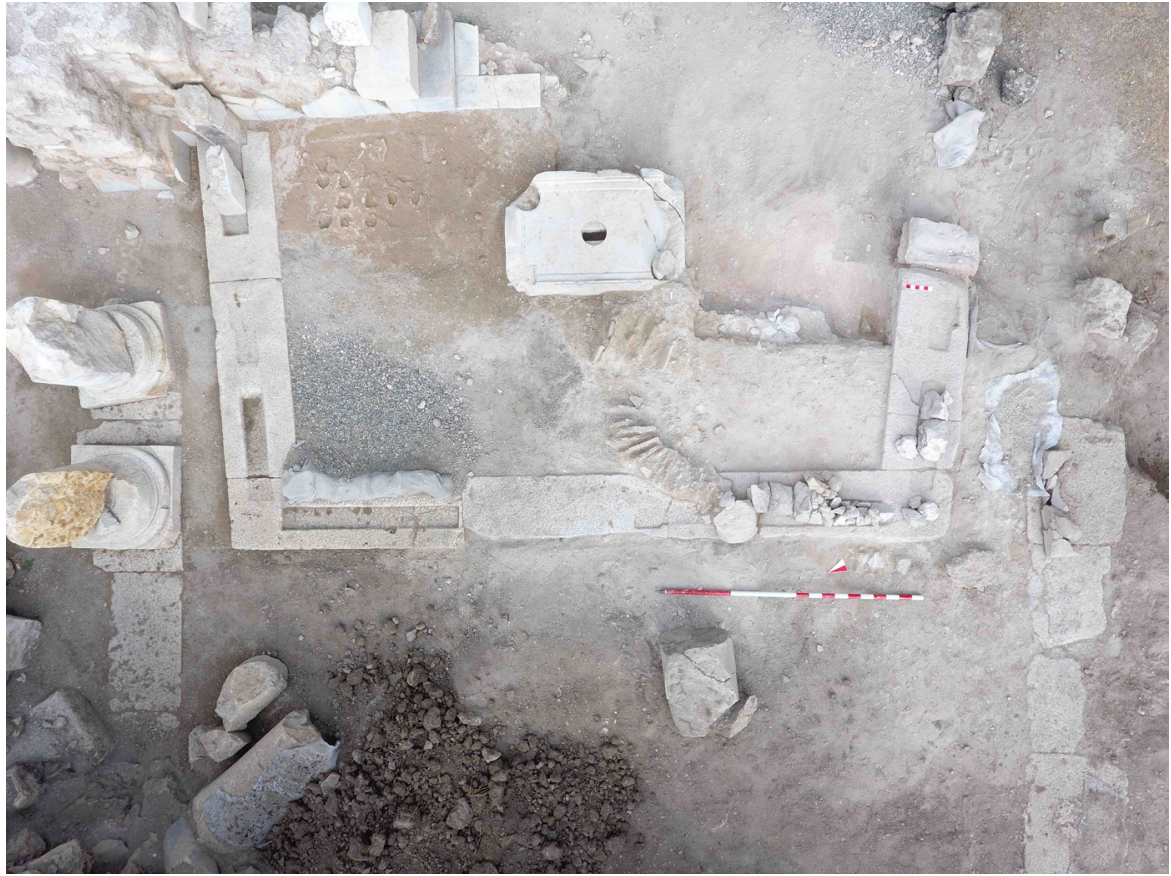

Resim 13

Opus Sectileli Pano İzleri

(Kazı Arşivi)

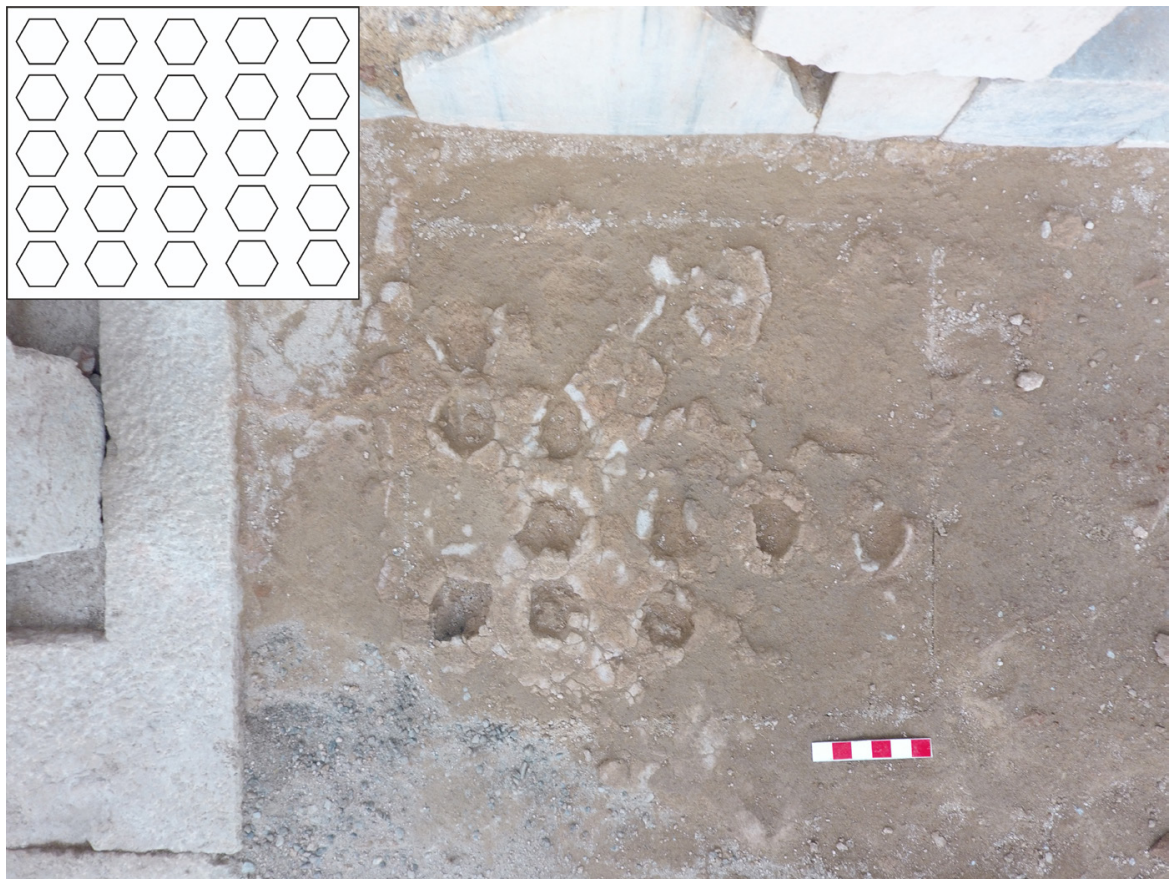

kuzeybatı köşesinde, gri damarlı Prokennesos (Marmara Adası) benzeri mermer plakalar ulaşmıştır ${ }^{16}$ (Res. 14). Mermer plakaların formuna ve konumuna bakıldığında ikinci evre zemin mozaiğindeki dörtgen panonun çerçevesi olarak düzenlendiği anlaşılmaktadır. İçerisi altıgen formlarla düzenlenmiş dörtgen pano şeklindeki opus sectile döşemenin benzeri Tarsus Roma Hamamı'ndaki zeminin 8 nolu panosunda (Adak Adibelli 2020: 55-56 res. 4-6) ve Olympos Antik Kenti'ndeki İS 5. - 6. yüzylla ait olan Episcopal Kilisesi'nde (Evcim Öztaşkın 2019: fig. 20/c) karşımıza çıkmaktadır.

16 Kuzeybatı köșesindeki mermer kaplı zeminin 120 x 30 cm, kuzeydoğu köședeki zeminin ise 90 x 87 santimetrelik kısmı korunabilmiştir. 


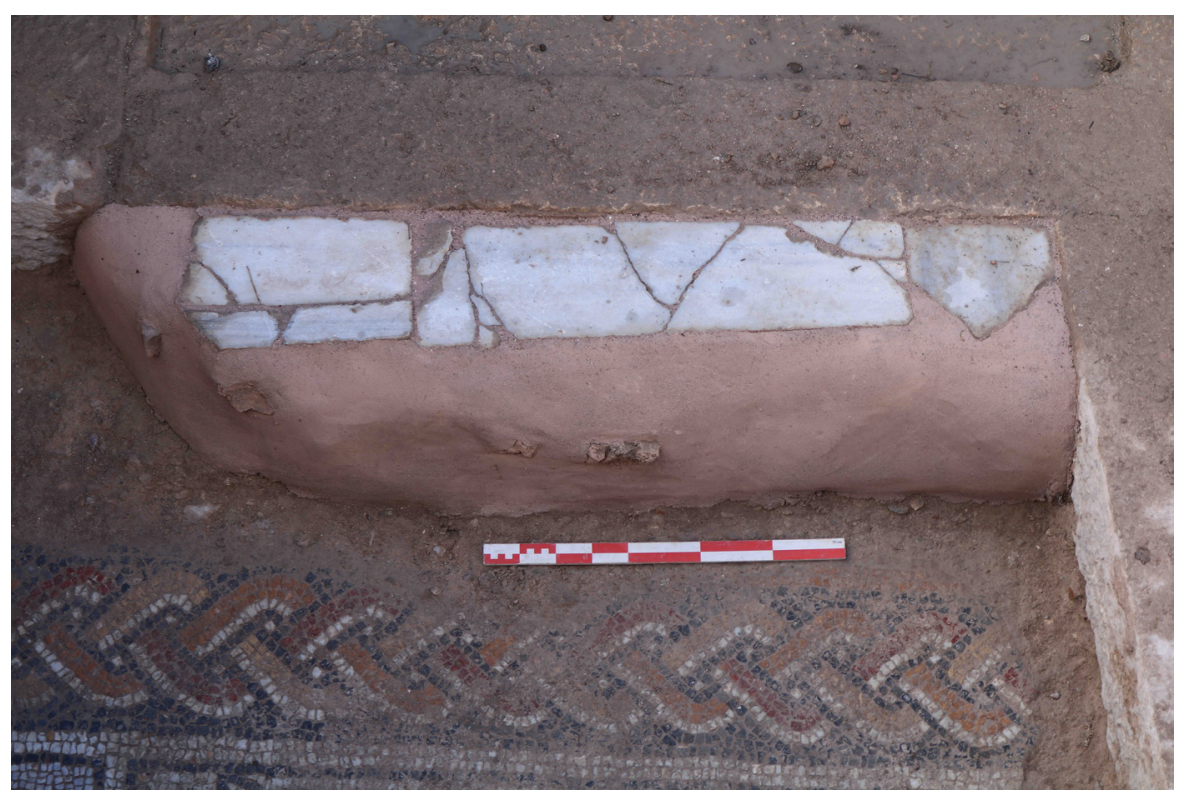

\section{Apsis Zemin Mozaiği}

İlk Evre: Kilise apsisinin ilk inşa evresindeki şekli kesin olarak bilinmemektedir, bununla birlikte kalan izlerden anlaşıldığı üzere içten yarım daire biçimli olduğu söylenebilir. İkinci evre apsis duvarının ilk evre zemini üzerine oturtulması, kilisenin doğu kısmından geçen modern karayolu yapımı esnasındaki çalışmalar ve kaçak kazılar sonucunda, apsis ve zemininin bir kısmı tahrip olmuştur. Özellikle batı kenarının orta kısmı, güney yarısı ve ana kompozisyonu çevreleyen bordür büyük oranda tahrip edilmiştir. Tahribatlara rağmen ilk evre zemin mozaiği büyük oranda sağlam vaziyettedir. Kalan izlerden anlaşıldığı üzere ilk evre apsis zemini, yarım daireye yakın bir alanı kaplar, içten $4.60 \mathrm{~m}$ genişlik ve $3.50 \mathrm{~m}$ derinliğe sahip olduğu söylenebilir. Balık pulu (Décor I: pl. 219b) dekorasyonundan oluşan ana süsleme alanı üç yönden, siyah-koyu gri renkli zemin üzerine üç halatlı giyoş (Décor I: pl. 72d) motifinin işlendiği, $30 \mathrm{~cm}$ kalınlıktaki ana bordürle çevrelenmiştir (Res. 15). Ana bordürün hemen dışında,

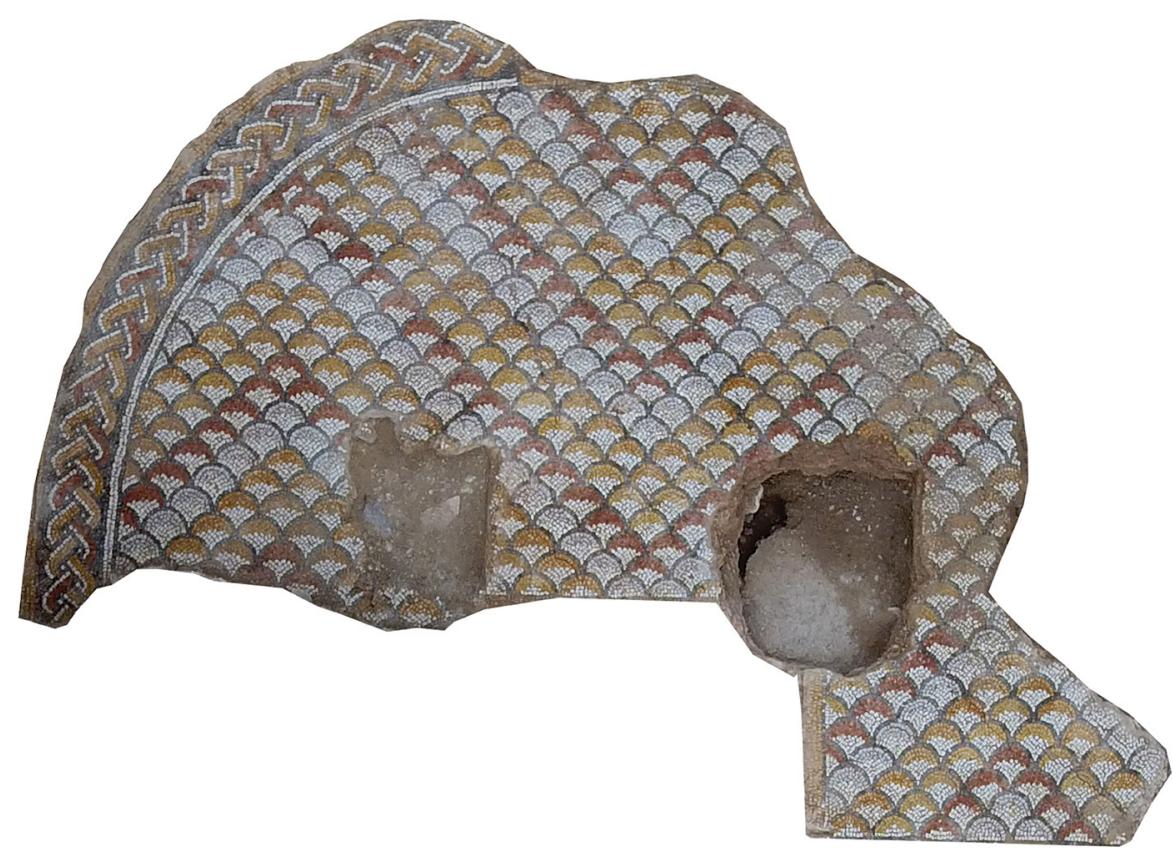

Resim 14

Bema İkinci Evre Zemini Kuzeybatı Köşesi (Kazı Arşivi).
Resim 15

Apsis İlk Evre Zemini Genel Görünüm (Kazı Arşivi). 
Resim 16

Apsisin Batısındaki Dikdörtgen Pano ve Kiborium İzi (Kazı Arşivi).

sarı renkli $10 \mathrm{~cm}$ kalınlıkta monokrom bordür yer alır. Bu bordürler bemayı çevreleyen bordürlerle aynı özelliktedir. Bu sebepten dolayı bema bordürü ile birleştiği düşünülmektedir, ancak bordürlerin kesiştikleri noktalardan kuzeyde yer alanı ikinci evre zemini altında kalması ve güneydeki noktanın ise tamamen tahrip olmasından dolayı kesin bilgi verilememektedir. Ana kompozisyonda balık pulu dekorasyonu görülür, bu dekorasyon peltae ve yarım daire motiflerinin diyagonal yerleştirilmesinden oluşmaktadır ${ }^{17}$. Her diyagonal sırada, peltae ve yarım daireler farklı renklerdeki tesseralardan yapılmışı1ı1 ${ }^{18}$. Bu şekilde apsis zemininde balık pulu dekorasyonunun içinde zikzak motifi de oluşturulmuştur. Ana dekorasyonun alt kisminda, orta eksene denk gelen noktada, monokrom sarı renkli bordürle çevrelenmiş, dikdörtgen bir panonun izleri görülmektedir (Res. 16). Bu kısım kiboriumla örtülü altarın bulunduğu alana denk gelmektedir. Panonun olması gereken ölçüsü 137 x 95 cm'dir. Bu panonun bir kısmı ikinci evre zemininin altında kalmış, geriye kalan kısmı da yol yapım esnasında veya kaçak kazılar sonucu tahrip edilmiştir. Panodan geriye kalan izler; doğu ve güney kenarında görülebilen $10 \mathrm{~cm}$ kalınlıktaki bordürden ibarettir.

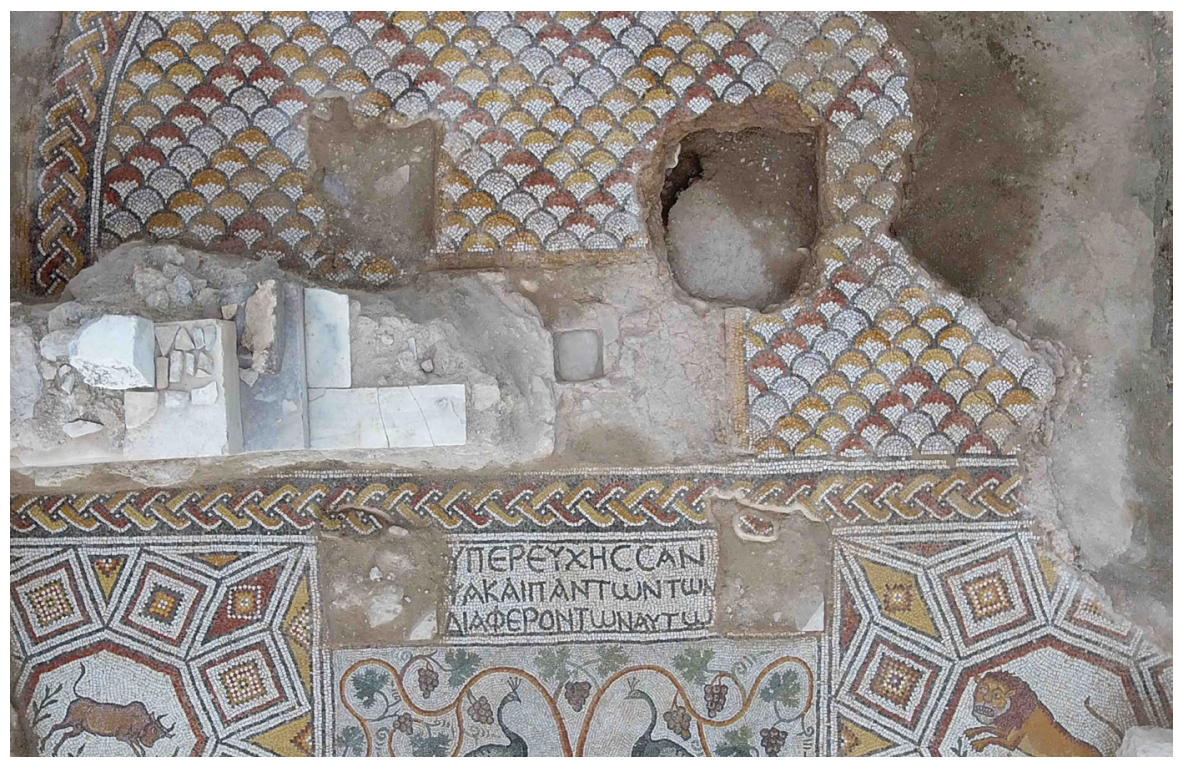

İkinci Evre: Apsis ikinci evre zemin mozaiği büyük oranda tahrip olmuştur, sadece bema-apsis arasındaki geçişte, mermer plakalarla kaplı bir bölümü görülebilmektedir. Bema ikinci evre zemini ile olan benzerliğinden dolayı ya opus sectile ile döşendiği ya da sadece mermer plakalarla kaplandığ düşünülmektedir. Kalan izlerden anlaşıldığı üzere, kilise ikinci evresinde, $1.70 \mathrm{~m}$ genişlikteki syntronunun, apsisin üç yönünde büyük alan kapladığ 1 görülmektedir. Bu durum, ikinci evre apsis zeminin, ilk evreye göre daha küçük boyutlu tasarlandığını gösterir. Mevcut kalıntılar ve yapılan hesaplamaya göre, ikinci evre apsis zemini, yaklaşık $2 \mathrm{~m}$ çapındaki yarım dairesel bir alandan oluşmaktadır.

17 Yarım dairelerden yola çıkılarak, balık pulu dekorasyonun aslında kesişen dairelerden oluştuğu söylenebilir, ancak daireler kesiştiği için bir kısmı gösterilmemiştir. Bu şekilde oluşan motife ise peltae adı verilmiştir. Dekorasyondaki yarım dairelerin çapları, 17-20 santimetredir. Palteaların uzunlukları 18-20 cm, genişlikleri 17-18 cm arasında değişmektedir.

18 Dekorasyona yukarıdan bakıldığında; vişne çürüğü-beyaz, gri-beyaz ve sarı-beyaz renkli peltae-yarım daire şeritler görülmektedir. 


\section{Değerlendirme ve Sonuç}

Bema ve apsis zeminini, ikonografik açıdan genel bir değerlendirmek gerekirse, cennet bahçesi (Eden) ve sonsuz yaşam konusunun işlendiği söylenebilir. Bema ortasındaki refrigerium sahnesi, antitetik yerleştirilmiş tavus kuşları ve kap içinden filizlenerek panoyu dolduran asma bitkisi cennet bahçesi temasını oluşturan öğelerdir. Bordürlerde görülen, sonsuzluk prensibinde ele alınmış örgü motifi, aslan ve boğa figürlü panoların kenarlarında işlenen yarım kalmış kare ve dikdörtgen motifleri (üçgenler), apsis dekorasyonunda, kenarlarda yarım kalmış biçimde ele alınan peltae ve daire motifleri ise sonsuz yaşam konusunu yansıtan unsurlardır. Yukarıda bahsedildiği üzere aslan ve boğanın, kilisenin en kutsal bölümlerinden biri olan bemada, özel panolar içerisinde resmedilmesi, bunların İncil yazarlarından Lucas ve Marcus'u sembolize ettiklerini düşündürmektedir. Ancak İncil yazarlarının aslan ve boğa olarak betimlendikleri örneklerde saldırı pozisyonunda resmedilmediği görülmektedir. Yine yukarıda değinildiği üzere, bu hayvanlara Bizans ve Hristiyan sanatından farklı anlamlar yüklendiği bilinir. Dolayısıyla panolardaki tasarımın, sanatçılar tarafindan hem dekoratif hem de sembolik amaçla yapıldığı söylenebilir.

Bema paneli ortasında yer alan, Eden bahçesi ve refrigerium konulu, kraterden filizlenen asma bitkisiyle doldurulmuş sahnenin, üslup ve içerik açısından benzer örneklerini Bizans İmparatorluğu Dönemi'nde inşa edilmiş birçok kilise ve yapıda görebilmek mümkündür. En yakın örneği, Hadrianoupolis Dört Nehir Kilisesi'ndedir (Res. 17). Kuzeybatı Nekropol Kilisesi'nden farklı olarak Dört

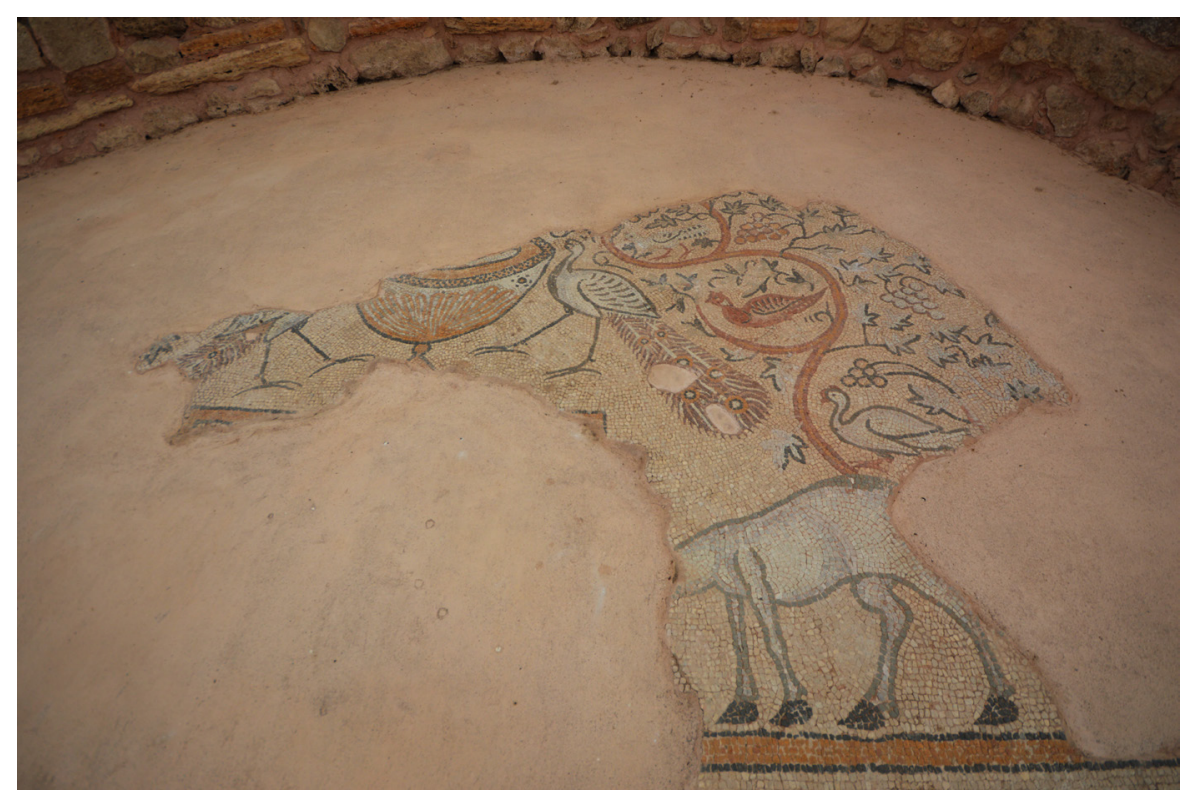

Nehir Kilisesi Mozaiği'nde, asma dalları arasında, beslenme pozisyonunda farklı kuş figürlerine yer verilmiştir (Verim 2019: 288) İmparatorluğun farklı bölgelerinde yer alan, Ma'on-Nirim Sinagogu (İS VI. yüzyıl) (Dunbabin 2003: 123), Elbeyli Köyü'nde hipoje mezar odasında (İS IV. yüzy1l) (Parman 1993: 394 res. 1), Apameia Kilisesi'nde (Balty vd. 1969: 13 fig. 4.2), Beth Shean Sinagogu (İS V. yüzy1l) (Hachlili 2009: 201 fig. IX.2-c,d), Sabratha Justinian Bazilikası (ISS VI. yüzyıl) (Maguire 1987: fig. 70), Apollonia Batı Kilisesi (İS VI. yüzy11) (Widrig - Goodchild 1960: 70-90), Düziçi Yapı Kalıntısı (ISS VI. yüzyılın ilk yarıs1) (Tülek 2006: 116), Altıntepe Kilisesi (ISS VI. yüzyıl. ortası) (Can 2009: 8-9), Heraclea Lynkestis Bazilikası (İS VI. yüzyıl sonu) (Maguire 1987: fig. 43; Dimitrova 2015: 203-218), Nikopolis St. Demetrius Şapeli (İS VI. yüzy1l.) (Kitzinger 1951: 85), Butrint Vaftizhanesi (İS VI. yüzy11.)
Resim 17

Hadrianoupolis Dört Nehir Kilisesi Apsis Zemini (Kazı Arşivi). 
(Maguire 1987: fig. I; Gilkes 2003: fig. 1.6), Durres-Arapaj Bazilikas1 gibi yapıların naos, apsis ve tonoz mozaiklerinde, benzer sahneler karşımıza çıkmaktadır. Hadrianoupolis Chora Kilisesi, orta nef zemin mozaiğinde de bu sahnenin benzerleri görülür (Patacı 2012: 78-79). Ancak buradaki kraterin içinden asma bitkisi filizlenmemektedir. Ayrıca sahnelerde, kapların iki yanında, tavus kuşu haricinde, ördek ve kaz figürleri de betimlenmiştir.

Hadrianoupolis Kuzeybatı Nekropol Kilisesi kazıları stratigrafik değerlendirmeye bağlı kalınarak yapılmaktadır. Stratigrafik açıdan şu ana kadar dört katman belirlenmiştir. Sikke, seramik, metal eserler ve cam eserler gibi kontekst buluntular ile mimari özellikleri 1şığında I. tabaka İS 8. yüzyıla, II. tabaka İS 7. yüzyılın sonu - 8. yüzyıl arasına, III. tabaka İS 5. - 6. yüzyıl arasına, IV. tabaka ise İS 4. - 6. yüzyıl arasına tarihlendirilmektedir. Mozaik zemin IV. tabakanın içerisinde yer almaktadır. Yani mozaik zeminin İS 4. - 6. yüzyıl arasındaki bir dönemde yapıldığı stratigrafik çalışmalar aracılığıyla anlaşılmaktadır. Yukarıda bahsedilen başka merkezlerdeki mozaik örnekler ve kontekst eserler 1şığında bema ve apsis mozaikleri İS 5. yüzyıla ait olmalıdır.

Hadrianoupolis Antik Kenti, Paphlagonia olarak adlandırılan coğrafi bölgenin Helenistik, Roma ve Bizans dönemine 1şı tutacak önemli arkeolojik verilere sahip bir kenttir. Özellikle antik kaynaklarda adı geçen Aziz Stylianos Alypius'un (Alypius Stylites) önemli bir figür olarak öne çıktığı dinsel hac yeri olarak ilgi gören kent, rahip ve rahibeler manastırları ile tanınmış, ayrıca Iustinianus döneminde önemli bir piskoposluk merkezi konumuna ulaşmıştır. Hadrianoupolis Antik Kenti, dini yapılar ve bu yapılarda ortaya çıarılan mozaikler üzerinde tasvir edilen çeşitli mitolojik yaratıklar, hayvanlar, bitkiler ve insan tasvirleri bakımından bölgenin en zengin mozaik çeşitliliğine sahip kentlerinden birisidir. Mozaikler antik dönem insanlarının duygularını, düşüncelerini, kısacası tüm hayatlarını geleceğe aktaran çok önemli vesikalardır. Dolayısıyla Hadrianoupolis’teki yapıların zeminlerini süsleyen eşsiz mozaikler bölgenin sanatsal ve kültürel tarihini de aydınlatmaktadır. Kentteki devam eden restorasyon çalışmaları neticesinde, mozaiklerin gelecek kuşaklara aktarılarak geçmiş ile gelecek arasında köprü kurulması amaçlanmaktadır. 


\section{Kaynaklar - Bibliography}

Adak Adıbelli 2020

Anđelković vd. 2010

Audsley - Audsley 1865

Balty vd. 1969

Belke 1996

Can 2009

Clement 1886

Çelikbaş 2019a

Çelikbaş 2019b

Décor I

Décor II

Deliyannis 2010

Dimitrova 2015

Dunbabin 2003

Evcim - Öztaşkın 2019

Ferguson 1961

Gilhus 2006

Gilkes 2003

Hoepfner 1966

Hachlili 2009

Kan Şahin 2019

Karademir 2019

Keleş vd. 2014

Keleş vd. 2015

Kılavuz - Çelikbaş 2013

Kitzinger 1951

Lafl1 - Zäh 2009

Lafl1 - Christof 2012

Leonhard 1915

Maguire 1987
I. Adak Adıbelli, “Tarsus Roma Hamamı Geç Antik Opus Sectile Döşemesi”, JMR 13, 51-71.

J. Anđelković - D. Rogić - E. Nikolić, "Peacock as a Sign in the Late Antique and Early Christian Art", M. Korać (ed.), Archaeology and Science 6, Belgrade, 231-248.

W. Audsley - G. A. Audsley, Handbook of Christian Symbolism, London.

J. C. Balty - P. Delvaux - K. Chéhadé - W. Van Rengen - C. Dulière, Mosaiques De L'eglise De Herbet Muqa, Bruxelles.

K. Belke, TIB 9: Paphlogonien und Honorias, Wien.

B. Can, "Erzincan Altıntepe Church with Mosaic", JMR 3, 5-13.

C. E. Clement, A Handbook of Christian Symbols and Stories of the Saints, Boston.

E. Çelikbaş, "Hadrianoupolis Kilise C Yapısı'nda Ele Geçen İki Adet Yün Tarağı Üzerine Değerlendirme”, TÜBA-KED 20, 73-82.

E. Çelikbaş, "Hadrianoupolis Kilise C Mozaikleri Konusunda Bir Ön Değerlendirme", A. Ișık - T. Aydeniz - İ. H. İmamoğlu (eds.), Uluslararası Geçmişten Günümüze Karabük ve Çevresinde Dini, İlmi ve Kültürel Hayat Sempozyumu, Karabük, 290-295.

C. Balmelle - M. Blanchard Lemée - J. Christophe - J.-P. Darmon - A.-M. Guimier Sorbets - H. Lavagne - R. Prudhomme - H. Stern, Le Décor géométrique de la mosaïque romaine I, Paris, 1985.

C. Balmelle - M. Blanchard-Lemée - J.- P. Darmon - S. Gozlan - M. P. Raynaud, Le Décor géométrique de la mosaïque romaine II, Paris, 2002.

D. M. Deliyannis, Ravenna in Late Antiquity, Cambridge.

E. Dimitrova, "The Mosaic at the Entrance of the Episcopal Basilica in Heraclea Lyncestis: Its Didactical Sharge and Ritual Impact over the Congregation”, Folia Archaeologica Balkanica III, 203-218.

K. M. D. Dunbabin, Mosaics of the Greek and Roman World, Cambridge.

S. Evcim - G. K. Öztaşkın, "Early Byzantine Churches in Olympos”, Arkeoloji ve Sanat Dergisi 161, 129-162. G. Ferguson, Signs \& Symbols in Christian Art, Oxford and New York, London.

I. S. Gilhus, Animals, Gods and Humans: Changing attitudes to animals in Greek, Roman and early Christian ideas, London-New Yok.

O. J. Gilkes, "Luigi Maria Ugolini and the Italian Archaeological Mission to Albania", O. J. Gilkes (ed.), The Theatre at Butrint, Oxford, 3-22.

W. Hoepfner, Herakleia Pontike - Ereğli: Eine Baugeschichtliche Untersuchung, Graz-Wien-Köln.

R. Hachlili, Ancient Mosaic Pavements: Themes, Issues and Trends Selected Studies, Boston.

G. Kan Şahin, “Bir Anadolu Eyaleti Olarak Honorias”, Karadeniz İncelemeleri Dergisi 14 (27), 11-42.

T. Karademir, Bizans Resim Sanatında Refrigerium Sahneleri, Yayınlanmamış Yüksek Lisans Tezi, Çanakkale Onsekiz Mart Üniversitesi, Sosyal Bilimler Enstitüsü, Çanakkale.

V. Keleş - E. Çelikbaş - A. Yılmaz. "Paphlagonia Hadrianoupolis'i”, H. Kasapoğlu - M. A. Yılmaz (eds.), Anadolu'nun Zirvesinde Türk Arkeolojisinin 40. Y1l1, Ankara, 271-290.

V. Keleş - B. N. Kılavuz - E. Çelikbaş - A. Yılmaz, "Hadrianoupolis 2013 Yı1ı Çalışmaları”, 36. KST, 1, 661670.

B. N. Kılavuz - E. Çelikbaş, "Paphlagonia Hadrianoupolis'i”, Tarih Kültür ve Sanat Araştırmaları Dergisi 2 (3), 159-214.

E. Kitzinger, "Studies on Late Antique and Early Byzantine Floor Mosaics: I. Mosaics at Nikopolis", DOP 6, 81-122.

E. Lafl1-A. Zäh, "Beiträge zur Frühbyzantinischen Profonarchitektur aus Hadrianupolis-Blütezeit unter Kaiser Iustinian I.”, ByzZ 102 (2), 639-659.

E. Lafl1 - E. Christof, Hadrianopolis I: Inschriften aus Paphlagonia, Oxford.

L. Leonhard, Paphlagonia: reisen und forschungen im nördlichen Kleinasien, Berlin.

H. Magiure, Earth and Ocean: The Terrestrial World in Early Byzantine Art, London. 
Oyarçin 2019

Parman 1993

Patac1 2012

Patac1 - Lafl1 2019

Roueché 1986

Schultze 1922

Simitopoulou vd. 2015

Tülek 2006

Verim 2019

Widrig - Goodchild 1960
K. Oyarçin, "Sikke Buluntuları Işı̆̆ında Hadrianoupolis Kilise C Yapısı”, A. Işık - T. Aydeniz - İ. H. İmamoğlu (eds.), Uluslararası Geçmişten Günümüze Karabük ve Çevresinde Dini, İlmi ve Kültürel Hayat Sempozyumu, Karabük, 442-451.

E. Parman, "Bizans Sanatında Tavus Kuşu İkonografisi”, Sanat Tarihinde İkonografik Araştırmalar: Güner İnal'a Armağan, Ankara, 387-412.

S. Patacı, Paphlagonia Hadrianoupolis’i Mozaik ve Fresko Buluntuları, Yayınlanmış Doktora Tezi, Dokuz Eylül Üniversitesi, Sosyal Bilimler Enstitüsü, İzmir.

S. Patac1 - E. Lafl1, Hadrianoupolis IV: Early Byzantine mosaics and frescoes from Northwestern central Turkey, Oxford.

C. Roueché, "Theodosius II, The Cities, and the date of the 'Church History' of Sozomen", The Journal of Theological Studies 37 (1), 130-132.

V. Schultze, Altchristliche Städte und Landschaften: II. Kleinasien, Gütersloh.

K. Simitopoulou - F. Siegmund - G. Kotzamani - Ch. Boutsidis - Ch. Papageorgopoulou, Depictions of Animal in Ancient Mediterranean Cultures \& Beyond: Reflections of a long-lasting co-evolutionary process, Komotini.

F. Tülek, “Türkiye Mozaik Çalışmaları: Kilikia Mozaik Külliyatı”, Arkeoloji ve Sanat Dergisi 123, 113-122.

E. Verim, "Paphlagonia'da Bir Piskoposluk Merkezi: Hadrianoupolis Antik Kenti”, A. Işık - T. Aydeniz - İ. H. İmamoğlu (eds.), Uluslararası Geçmişten Günümüze Karabük ve Çevresinde Dini, İlmi ve Kültürel Hayat Sempozyumu, Karabük, 276-289.

W. M. Widrig - R. Goodchild, "The West Church at Apollonia in Cyrenaica”, BSR 28, 70-90. 
